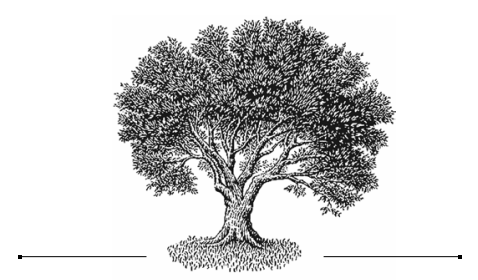

Археолошки

сведоштва за

дејноста на Свети

Кдимент Охридски

во Охридскиот

регион
Археологические

свидетельства

деятельности

свт. Климента

Охридского в

Охридском регионе

\section{Паско Кузман}

Заводот за заштита на спомениците на културата и Народен музеј во Охрид, Охрид, Македонија

\section{Паско Кузман}

Управление по защите памятников культуры и Национальный музей в Охриде, Охрид, Македония

\title{
Апстракт
}

Со дејноста на Св. Климент Охридски е сврзано градењето на црквата и манастирот на Плаошник во Охрид. На почетокот за богослужбени потреби се искористени остатоци од една мала градба со триконхална основа, која што св. Климент ја обновил, а потоа кон неа бил дограден погодем "пронаос" со крстовидна форма, каде што подоцна бил погребен Светителот (916 г.). Во почетокот на X век триконхалната црква од манастирот на св. Климент била искористена како идеален модел за изградба на црквата во манастирот на св. Наум на јужниот дел од Охридското Езеро. Уште една црква со триконхална основа била изградена на брегот на езерото во месноста Горица близу Охрид, градба која најверојатно припаѓала на истиот период. Во околината на селото Злести, триесеттина километри северно од Охрид, во месноста Долна Дебарца, исто така, се наоѓаат архитектонски остатоци од триконхална црква од истото време, а во околината на селото Издеглавје во месноста Горна Дебарца се откриени остатоци од двоконхална црква која што истражувачите, исто така, ја поврзуваат со времето на Св. Климент Охридски. 
Клучни зборови

Климент Охридски, Охрид, Плаошник, археолошки ископувања, триконхос, Климентовиот манастир, Наум Охридски, Горица, Злести, Издеглавје

\section{Резюме}

С деятельностью свт. Климента Охридского в Охридском регионе связано прежде всего строительство церкви и монастыря в Охриде. Этот монастырь был создан в конце IX в. на месте, где ранее находилась одна из византийских базилик V в. Как показали результаты археологических исследований, в начале свт. Климент перестроия и приспособил для богослужебного употребления небольшую постройку триконхальной формы, которая была построена ранее на месте разрушенной базилики. Затем к этому триконху был пристроен большой пронаос крестовокупольной формы, где позднее был погребен свт. Кдимент. Характерной особенностью этого пронаоса было надичие входов с северной и южной стороны, тождественных входам в крестовокуподьную церковь конца IX - начала X вв. около села Вельча (Velçё) в долине реки Шушица (Южная Албания). Во время архиепископа Дмитрия Хоматиана (1216-1236) “пронаос" был разобран, и на его основании была построена новая церковь, в которой были положены мощи свт. Климента. В османский период монастырь и церковь свт. Климента были разрушены, и затем на месте церкви была построена мечеть. В самом начале X в. триконхальная церковь в монастыре свт. Климента была использована в качестве образца при строительстве церкви в монастыре св. Наума в южной части Охридского озера, которая также была перестроена в османский период. Основания еще одной церкви триконхальной формы, строительство которой можно отнести ко времени свт. Кдимента, были обнаружены в месте Горица около Охрида. Около села Злести в местности Долна-Дебарца недалеко от Охрида сохранились руины триконхальной церкви, которая относится к рассматриваемому периоду, а около с. Издеглавье в местности Горна Дебарца находится двуконхальная церковь, строительство которой также связывается с деятельностью свт. Климента Охридского.

\section{Ключевые слова}

Климент Охридский, Охрид, Плаошник, археологические раскопки, триконх, монастырь свт. Климента, Наум Охридский, Горица, Злести, Издеглавье

Во археолошка смисла периодот од IX до X век е најмалку присутен со материјално културно наследство во Охридскиот регион, особено во поглед на културни слоеви со движни артефакти. Ова сигурно се однесува на скромните можности на доминантното домородно словенско население, на филозофијата на живеење на штотуку христијанизираните словенски маси и на општествено-политичките околности во тоа време кое го вклучувало овој регион во помала мерка во рамките на византискиот комонвелт и во рамките на територијалното присуство и доминација на I Бугарско царство. Во истата таа археолошка смисла треба да се потенцира дека релативно малку се вршени археолошки истражувања кои биле главно насочени во разоткривањето на недвижното културно 
наследство поврзано со Светиклиментовата дејност, поточно во разоткривањето на остатоците од сакралните објекти (триконхални цркви) кои ги изградиле Светите Климент и Наум спомнувани во нивните Житија, кои директно ги изведувал и резултатите првично ги објавил само еден истражувач (Димче Коцо) [Коцо 1948: 129-180; IDEM 1958: 56-80].

Првите археолошки активности се изведени 1942-1943 година од страна на Службата за старини во Охрид под раководство на Кирил Прличев (син на познатиот поет и преродбеник Григор Прличев) кога во внатрешноста на Султан Мехмед џамијата (Сл. 1) на Плаошник (“Имарет”) биле откриени архитектонски остатоци од Светиклиментовата црква, фрагменти од живопис и гробни конструкции меѓу кои сигурно и Светиклиментовиот гроб. Сите сознанија од овие зафати стручно ги разработил и објавил спомнатиот Д. Коцо, кој по К. Прличев бил поставен за управител на Службата за старини. Истиот натака ги извршил првите археолошки истражувања во црквата Св. Арханѓели во манастирот Св. Наум (1955-1956 г.) и ги раководел дополнителните археолошки истражувања на просторот од црквата во внатрешноста и околу џамијата на “Имарет” (Плаошник) во 1965 година [Коцо 1967А: 245-255].

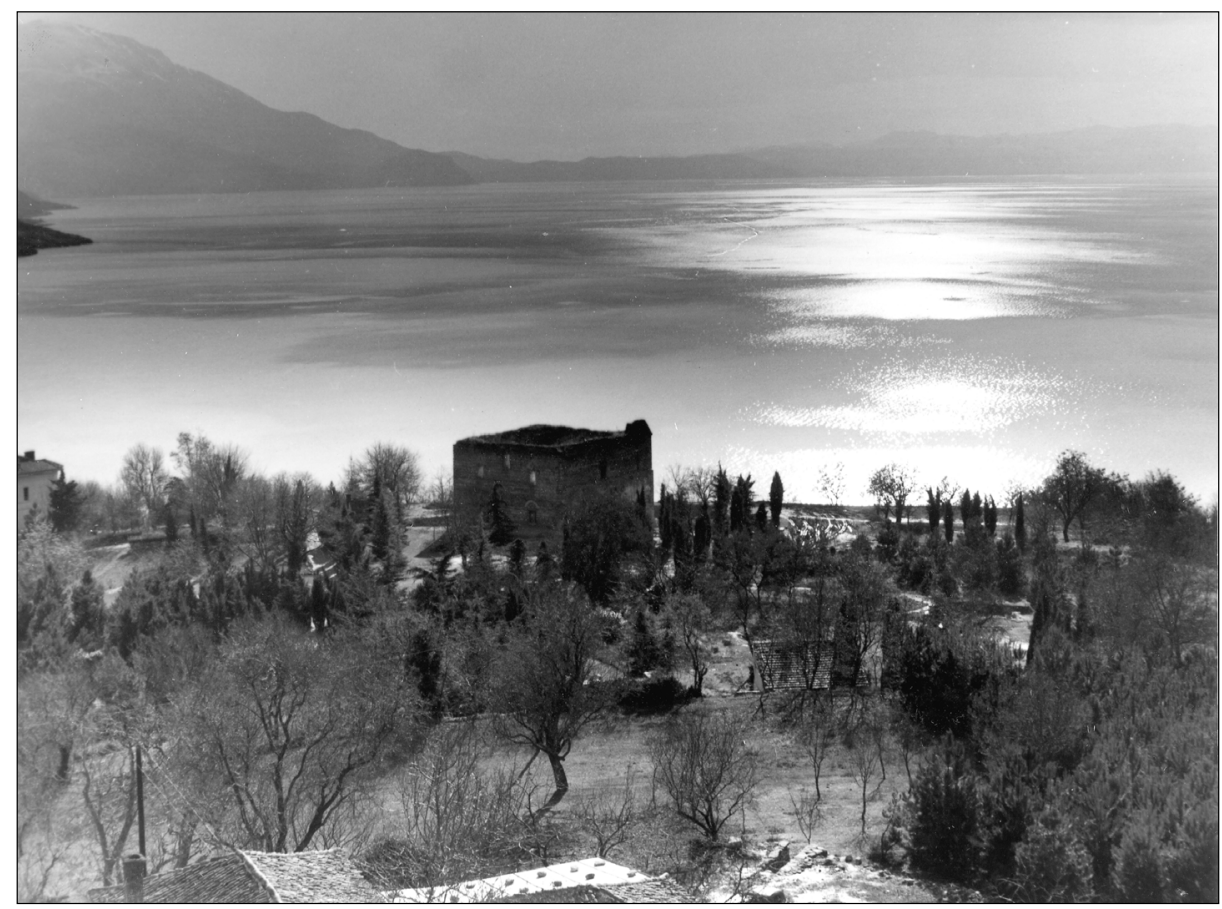

Сл. 1. Плаошник пред археолошките истражувања и возобновувањето на Светиклиментовата црква. 
Најголемите археолошки и конзерваторско-реставраторски активности на Плаошник се изведоа во времето на реализацијата на проектите: Возобновување на Светиклиментовата црква (1999-2002 г.) и Возобновување на комплексот “Светиклиментов универзитет” (2007-2016 г.), од кои резултатите не се целосно објавени, бидејќи, меѓу другото, реализацијата на вториот проект се́ уште трае. ${ }^{1}$

\section{Охрид - Плаошник}

Имајќи ги предвид вкупните сознанија од археолошките истражувања на Плаошник ${ }^{2}$ потребно е да ги потенцираме најзначајните археолошки откритија кои го осветлуваат континуитетот на живеење на овие простори на јужниот дел од повисокиот охридски рид, просторот-зарамнето плато меѓу Самуиловата тврдина/цитадела и средновековната црква Св. Јован Богослов-Канео, која пак се наоѓа на истурениот карпест гребен кој се спушта во југозападниот дел од ридот во водите на Охридското езеро (Пл. 1). Овие истражувања покажаа дека плаошничкиот крајолик не можел да биде заобиколен од ниедна популација која на било кој начин стигнала до него, а стратиграфските архиви покажаа дека тоа континуирано се случувало од големата завршница на праисторискиот период до доцниот среден век и до денес. Инаку, најстарите жители на Охрид живееле во низината покрај езерото источно од Охридскиот рид во куќи кои ги граделе на дрвени платформи подигнати на дрвени колци во мочурливиот терен покрај брегот на езерото (палафитна населба на

1 Види фуснота 2. Некои информативни резултати од овие зафати парцијално се објавеНИ во: [ГРОЗДАНОВ ЕТ AL. 2003; МАЛЕНКО 2004; БИТРАКОВА ГРОЗДАНОВА 2006; ПОЧУЧА КУЗМАН, АЦЕСКИ 2008; ПОчУЧА КУЗМАН ЕТ AL. 2008А; ПОЧУЧА КУЗМАН ET AL. 2008Б; ТутковСКИ 2014].

2 1942/1943 година - Кирил Прличев, кој ги разоткрил темелите и дел од другите архитектонски остатоци од Светиклиментовата црква во внатрешноста на Султан Мехмед џамијата во улога на Управител на Службата за старините во Охрид, на кое место потоа го наследува младиот Димитар Коцов (алијас Димче Коцо) кој подоцна ги публикува резултатите во трудот [Коцо 1948]; Август/септември 1965 година - археолошко-конзерваторски истражувања (Д. Коцо, Ж. Винчиќ, Тодор Паскали); археолошки истражувања, конзерваторско-реставраторски работи и презентација на архитектонските остатоци и мозаичните подови на комплексот ранохристијанска поликонхална црква кој се наоѓa на 50 м северно од Светиклиментовата црква во кампањи од 1958. До 1965/1967 г. - Д. Коцо, В. Лахтов, В. Битракова, В. Маленко, Тодор Паскали; 1999-2002 година Ревизиони и систематски археолошки истражувања, дислокација на остатоците од Султан Мехмед џамијата и Возобновување на Светиклиментовата црква “Св. Пантелејмон” врз темелите од остатоците на црквата (В. Маленко, Тања и Тодор Паскали, Н. Почуча Кузман, Одбор за возобновување на Светиклиментовата црква); 2007-2015 година - Систематски археолошки истражувања на целиот простор од локалитетот Плаошник, конзерваторскореставраторски работи и Возобновување на комплексот Светиклиментовиот универзитет (П. Кузман, В. Битракова Грозданова, Н. Почуча Кузман, Одбор за возобовување на комплексот “Светиклиментов универзитет”). 


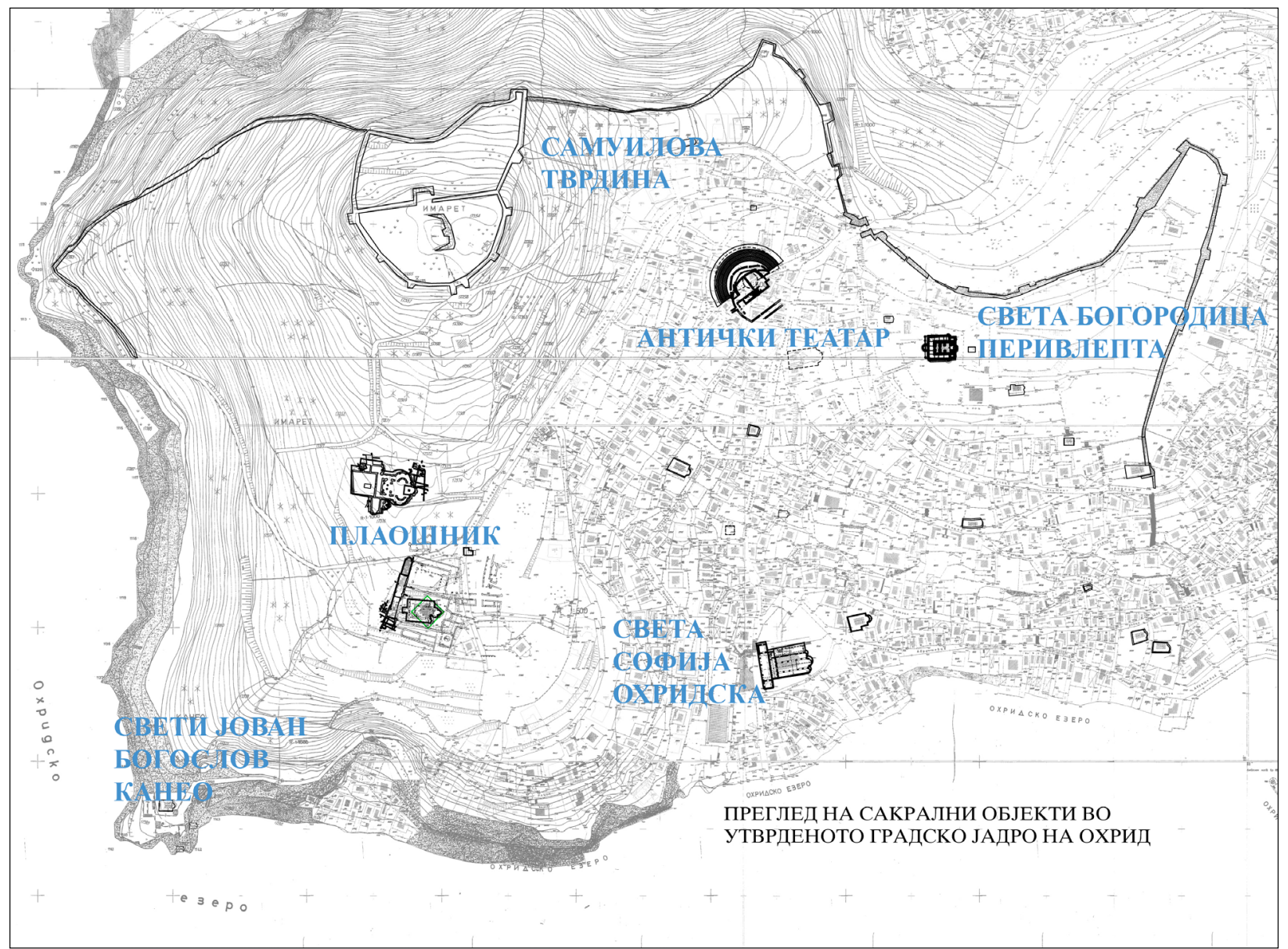

Пл. 1. Подлога со преглед на сакралните споменици во старото јадро на Охрид. 
археолошкиот локалитет Пенелопа) уште во времето на крајот од раниот неолит (6000 години пред н. е.) [КузмАн 2013: 321-324, 351-361]. Кон крајот на бронзеното време (околу 1200 г. пред н. е.) се развила првата праисториска населба на Плаошник (времето на т. н. мат сликана керамика). Во развиеното железно време (VIII-VII/VI век пред н. е.) на Плаошник почнала да се создава традиција за култност, лечебна aura popularis, одблесок на светлина и светост која ги озрачува боговите. Имено, во културните слоеви и гробовите од тоа време на Плаошник се откриени таканаречените култни бронзи (“култен накит”, “Пајонски бронзи”, “Македонски бронзи”) кои се поврзуваат со извесни религиозни, ритуални или апотропејски значења. Потоа, со поновите археолошки истражувања во аналитичка релација со постарите наоди (епиграфски и други) на истиот овој простор во античкиот период имаме индиции за постоење на пагански храмови. Во македонско-хеленистичкиот период имало и профани градби за живеење со улица меѓу нив, а во раноримскиот била изградена велеубава палата и бањи со пространи кади и прекрасни мозаични целини (I век пред н. е.) во северниот дел од локалитетот, каде што подоцна (V век н. е.), ќе биде подигната монументалната поликонхална црква.

Појавата на христијанството во Лихнидос (Охрид) се врзува за мисионерската дејност на Св. Апостол Павле. Кон крајот III век во Лихнидос дошол христијански проповедник Св. Еразмо од Антиохија, за кого се вели дека покрстил 20000 лихниѓани. На неколку километри северозападно од Охрид во 1974 година беше откриена ранохристијанска тробродна базилика (V-VI век) со нартекс, пастофории, атриум и крипта во апсидалниот простор со мошти од светецот Св. Еразмо [МАлЕнко, КузмАн 1988: 89-91, 94-96], кој по враќањето од Формија (Италија) продолжил да проповеда во градот Хермелиј (Хермелеја), недалеку од Лихнидос, каде и што умрел на 2 јуни 303 година. Инаку, уште во првата половина на IV век од римската провинција Македонија се изделила провинцијата Нов Епир, чија источна граница била 13 милји од Лихнидос, а овој град се спомнува како епископско седиште кое, најверојатно, во потесна смисла, се наоѓало на Плаошник. Првиот познат лихнидски епископ Дионисиј бил заведен во актите на црковниот собор во Сердика (343 г.) како Dionysius de Macedonia de Lychnido, вториот познат лихнидски епископ бил Антониј кој учествувал на Екуменскиот собор во Халкедон (451 г.), третиот Лаврентиј, кој поради наклонетоста кон папската столица во Рим бил прогонет од Лихнидос и четвртиот Теодорит, кој официјално ја изразил верноста на лихнидската епископија кон верската политика на римскиот папа [БитрАКовА ГроздАновА 1975: 16-20]. Ова е таканареченото Време на базиликите во Охрид кога се граделе 
монументални ранохристијански објекти со рустични екстериерни архитектоники и раскошни ентериерни изгледи со ьидни и подни мозаични површини. Само на просторите од старото градско јадро досега се евидентирани остатоци од единаесет ранохристијански базилики и цркви од V-VI век (девет тробродни од кои две на Плаошник и седум во другите простори од стариот дел на градот, и две поликонхални цркви од кои една на Плаошник и друга во источното подножје од Самуиловата тврдина-цитадела) како и уште две базилики во непосредна близина до градот (една кај “Св. Еразмо” и втора кај Студенчишта), сите со раскошни мозаични подни површини.

На Плаошник, кон крајот на антиката и во времето на рановизантискиот период (кон крајот на $\mathrm{V}$ век), се подигнува монументална тробродна базилика со нартекс, баптистериум и атриум, со раскошна архитектура и богати мозаични подови (Јужна базилика) [БИтрАковА ГроздАноВА 2006: 261-268; Тутковски 2014: 97-135]. Непосредно до неа, северно и источно, веќе функционирал плоштад украсен со крупен мозаик (opus barbaricum) и монументална цистерна (IV-V век). Речиси во исто време, малку подоцна (втора половина на V век), посеверозападно од овој објект е подигната монументална, би се рекло “царска”, поликонхална (четириконхос) црква со раскошни подни и sидни мозаици, нартекс, странични анекси, баптистериум и катехуменум (Поликонхос) [Коцо 1967ь: 257-263; БитрАковА ГроздАновА 1975: 22-67]. Овој монументален објект бил изграден врз остатоци од античко-римски профани згради со раноримски мозаични подови (палата со бањи, цистерна). Североисточно за педесеттина метра од Јужна базилика, се наоѓала уште една тробродна базилика од V век со мозаични подови (Источна базилика), нецелосно откриена со последните систематски археолошки истражувања (20072009 г.).

Во рамките на целиот овој густ простор од големи сакрални архитектонски објекти од времето на раното христијанство, поточно на “просторот од презвитериумот и источниот дел од наосот” на срушената монументална тробродна базилика ( Јужна базилика) по голем пожар бил изграден, според охридскиот археолог В. Маленко, “триконхос, со отворен трем од западната страна, којшто е прототип на триконхалниот баптистериум од поликонхалната базилика” [МАлЕнко 2004: 285]. Оваа констатација секако е индикативна бидејќи навистина баптистериумот (крстилницата) од поликонхалната црква изграден заедно со црквата во втората половина на $\mathrm{V}$ век е идентичен со обновениот Светиклиментов триконхос, со таа разлика што архитектонските елементи меѓу источната конха северно и јужно и северната и јужната конха кај овој триконхос се полукружни и од надворешната и од внатрешната страна, додека 
истите тие архитектонски делови кај баптистериумот од поликонхосот се аглести. Ова пак наведува на помислата дека врз еден простор од изгорената тробродна базилика некаде набрзо по пожарот била подигната помала триконхална спомен црква по угледот на триконхалниот архитектонски склоп од крстилницата на поликонхалната црква. Како што наведува В. Маленко, врз основа на постарите истражувања (1948-та и 1965-та од Д. Коцо) и врз основа на резултатите од најновите ревизиони истражувања (1999-2002 г.), овој претклиментов триконхос бил изграден со материјал од изгорената базилика и во опус со редови од тули и варов малтер со иста дебелина колку и тулите и бил со три полукружни конхи и од внатрешната и од надворешната страна (Пл. 2).

Периодот VII-VIII век за Охрид е исполнето со “историски” вакуум, освен археолошките податоци на Д. Коцо за кружните старословенски огништа околу кои имало примитивни објекти-колиби вкопани во мозаичните подови од наосот на поликонхалната црква, од крајот на VI век [Коцо 1967ь: 261]. Имено, тогаш како резултат на засилената словенска колонизација, биле до темел урнати сите профани и црковни објекти, а Лихнид (Охрид) станал дел од “Склавинијата Берзитија”. Во текот на VIII и првата половина на IX век, кога Охридскиот крај се развивал независно во рамките на склавинијата Берзитија, христијанството продирало главно преку потчинетите староседелци-христијани [ПАнов 1985: 188]. По паѓањето на Охридскиот крај под бугарска власт во средината на IX век, христијанизацијата особено се засилила. Со тоа завршува

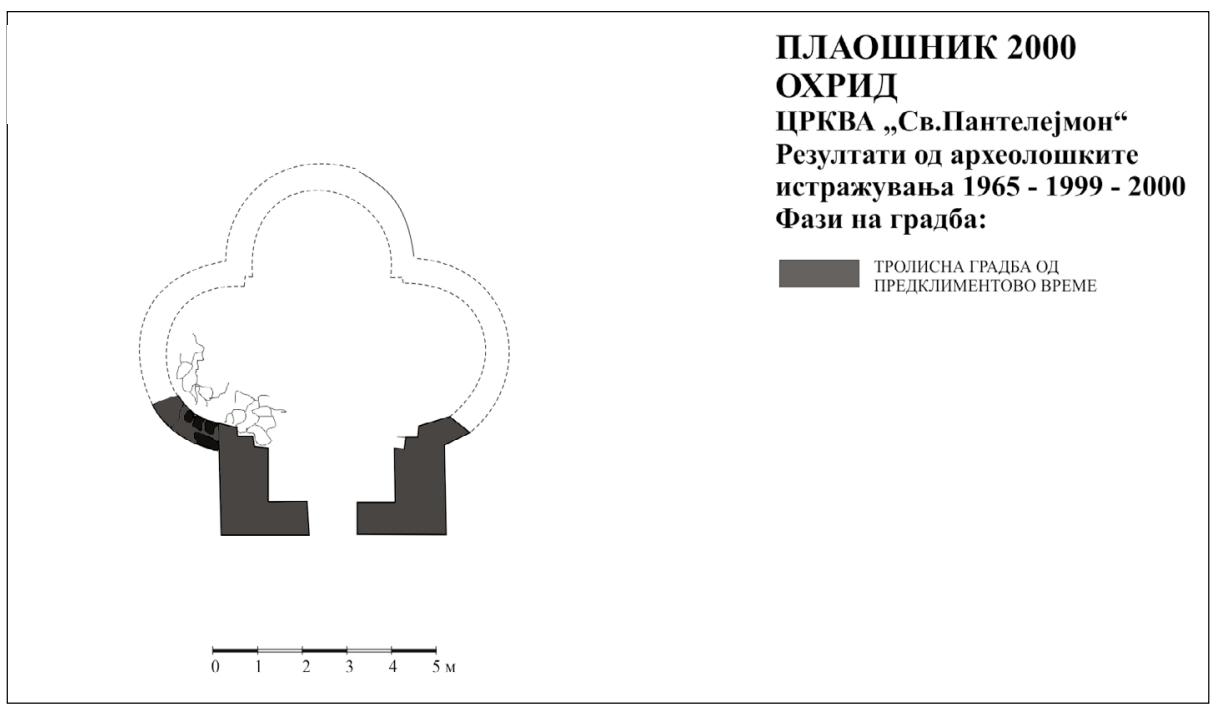

Пл. 2. Основа на разрушениот триконхос пред обновата од Св. Климент (цртеж: Тодор и Тања Паскали). 
протоклиментовиот период и започнува Светиклиментовото време во Охрид, по 886 година, по неговото доаѓање во областа на Кутмичевица (Југозападна Македонија и Јужна Албанија) која тогаш била во рамките на I Бугарско царство.

\section{Плаошник: Светиклиментовиот манастир}

Набрзо после почетокот на својата дејност во Кутмичевица светителот Климент изградил манастир на Плаошник [Туницкий 1918: 127]. Со Климентовата интервенција во крајот на IX век триконхосот, порано изграден на просторот од срушената јужна базилика, добил нови архитектонски елементи, односно источната конха станала тристрана од надворешната страна со два правоаголни засеци во западните делови северно и јужно, полукружна од внатрешната страна и со две функционални полукружни ниши изведени меѓу неа (источната конха) и меѓу двете други конхи (северната и јужната) кои се лачни и од внатрешната и од надворешната страна (Пл. 3). Триконхосот имал купола, која се потпирала врз архитектонската структура на конхите и нишите. Подот од обновениот од Климента триконхос бил изграден со мозаик во техника opus sectile, додека стариот од мермерни четвртести плочки [МАлЕнко 2004: 286].

Натака, уште додека Климент бил жив, најверојатно по неговото назначување за епископ, тој го проширил обновениот триконхален храм кон запад, со што истиот добил наос (“пронаос”) со четири зидани

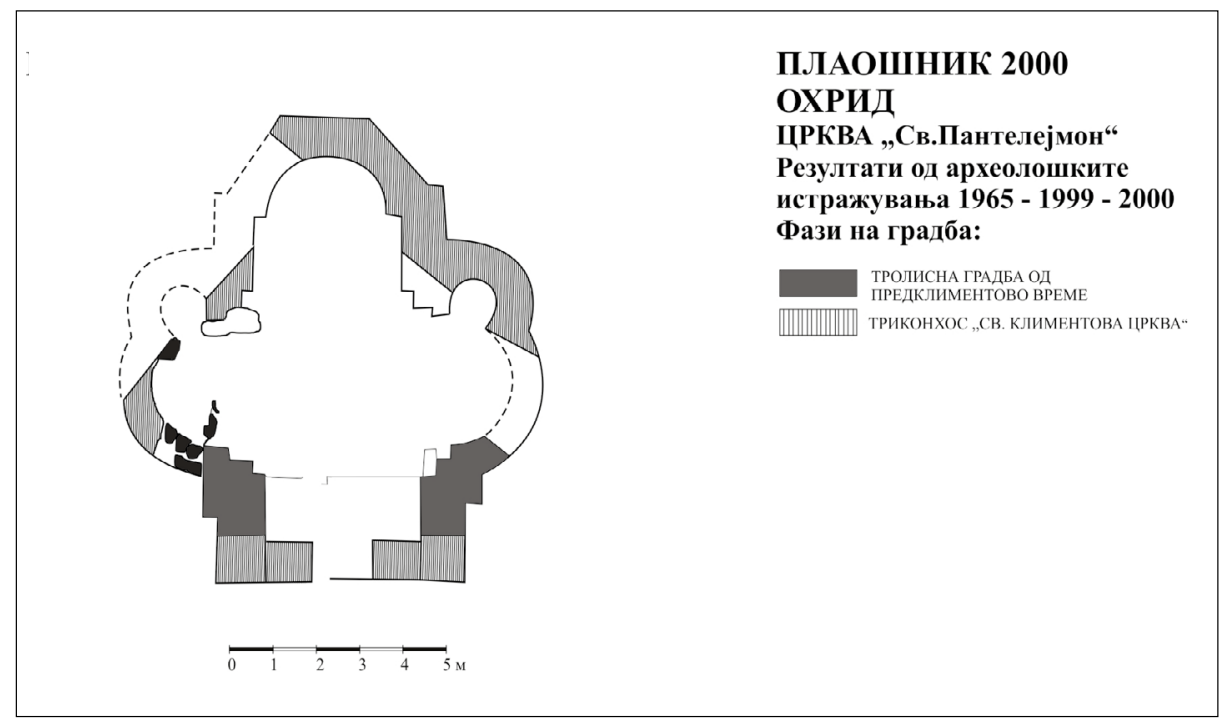

Пл. 3. Основа на триконхосот по обновата од Св. Климент (цртеж: Тодор и Тања Паскали). 
столбови подигнати врз четири бази (откриени при истражувањата, југоисточниот недостасува) во централниот простор, а кои носеле купола во средината, со што црквата добила форма на впишан крст (Пл. 4). Наосот имал влезови од северната и јужната страна, а се влегувало од помали отворени тремови, како и нартекс од западната страна со влезна партија кон исток, односно со влез во наосот. Со ова проширување се отстраниле довратниците од влезот во триконхалниот простор и со тоа се создале услови за поставување на олтарна преграда со што “триконхосот добива литургиска функција на олтар” [МАленко 2004: 286]. Пристап во триконхалниот олтар обезбедува влезот, кој бил тогаш направен меѓу северозападниот столб и северната конха. Со археолошките истражувања се констатира и местото на чесната трпеза, која била лоцирана во триконхосот во средината меѓу западните делови на северната и јужната конха (Сл. 2).

Во доградениот наос Климент уште додека бил жив си изградил гроб и во него бил погребен по смртта во 916 година [Туницкий 1918: 135]. Со “раскопката” во 1942-1943 година, за која Д. Коцо не наведува кога е изведена, а ја толкува во наведениот труд објавен 1948 година, се открива гробната конструкција на Светиклиментовиот гроб, која се наоѓa во југоисточниот дел од “прибавката” на Климентовиот триконхос, во кој дел бил откриен уште еден гроб, ама врз основа на in situ

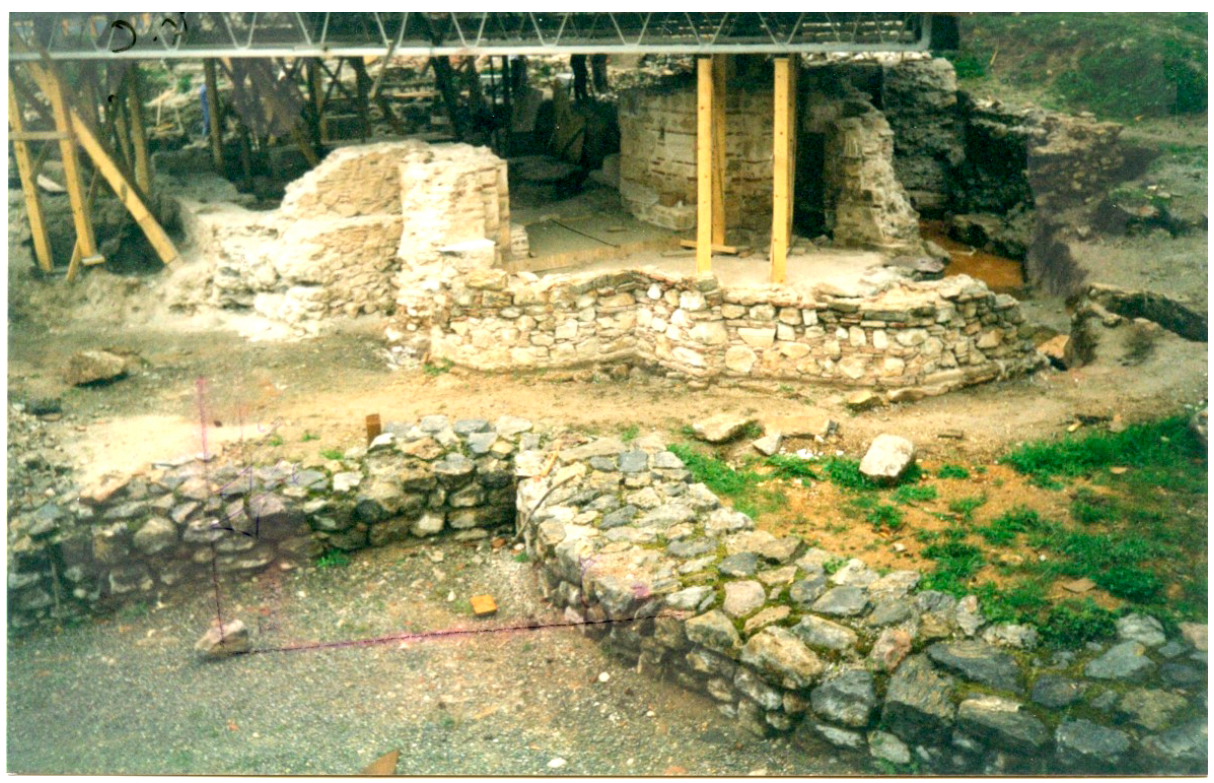

Сл. 2. Архитектонски остатоци од Светиклиментовиот триконхос по истражувањата во 1965 г. 


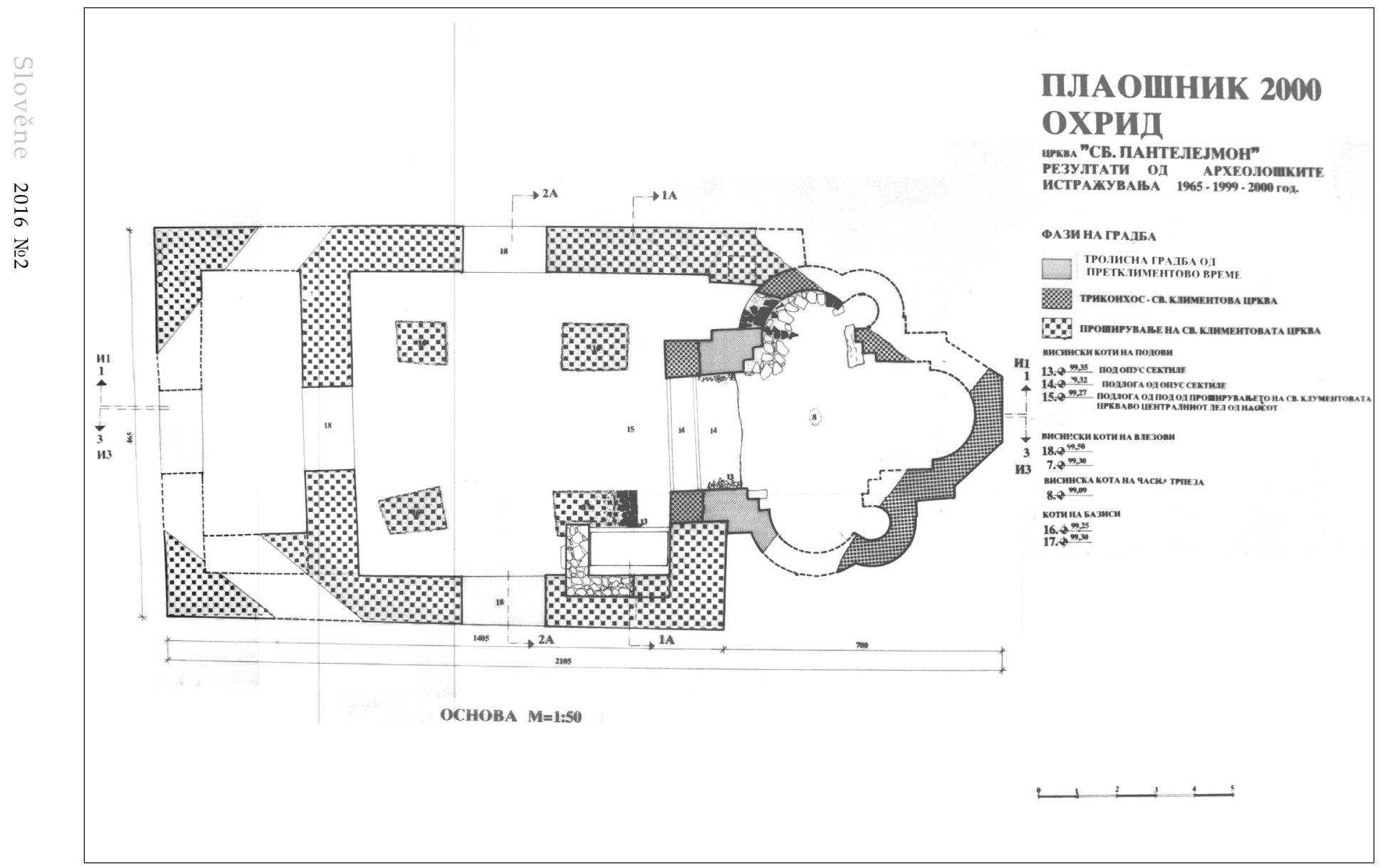

Пл. 4. Проширување на триконхосот кон запад во времето на Св. Климент (цртеж: Тодор и Тања Паскали). 
околностите и врз основа на податокот од “Житието на Св. Климент” од архиепископот Теофилакт ("од десната страна на предниот дел од пронаосот” [IBID.: 135]), Д. Коцо го идентификува Светиклиментовиот гроб (Сл. 3; Цртеж 1). Тој бил сомидан од редови тули поврзани со

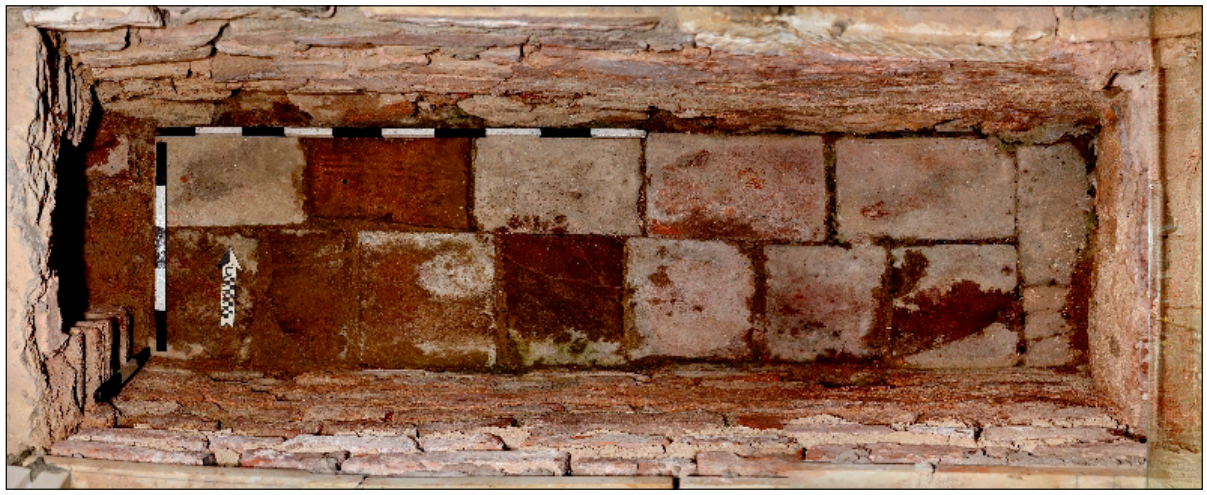

Сл. 3. Светиклиментовиот гроб во црквата на Плаошник (фото: Бојан Танески).

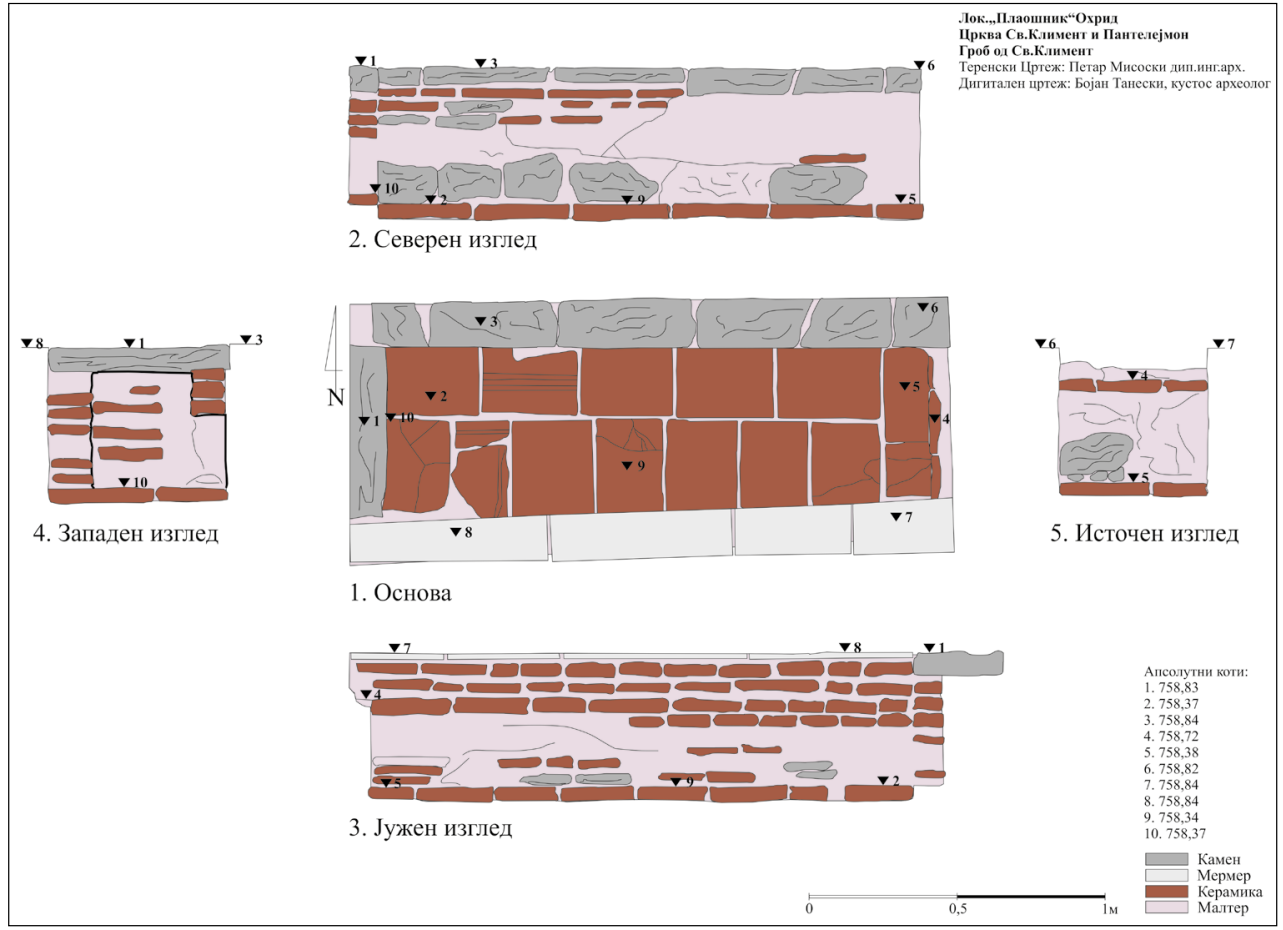

Цртеж 1. Светиклиментовиот гроб во црквата на Плаошник (Петр Мисоски; дигитал.: Бојан Танески). 
хоросан и фугирани. Основата на гробната јама ја сочинуваат два реда од керамички опеки поставени над слој од хоросан. Заедно со мала ниша на западната страна, должината на гробот изнесува 2,00 м (без ширината на западниот sид). При обновата на црквата во првата половина на XIII век (времето на архиепископот Димитриј Хоматијан) во источниот sид на гробот е изградена уште една правоаголна ниша. Најголема широчина на гробот изнесува 1,04 м, а височина 0,42 м. Ширината на гробната јама изнесува 0,62 м (кај нозете 0,53 м), а длабочина 0,48 м. Самиот гроб, според Д. Коцо, има форма на ковчег за погребување [Коцо 1948: 131-135 (за локацијата на гробот), 165 (за описот на гробот, подоста конфузен)].

Кога сме веќе “во времето” кога Климент ја доградил триконхалната црква, незаобиколно ни се налага, од археолошки аспект, да кажеме само неколку реченици и за Светиклиментовите “три цркви” кои ги спомнува архиепископот Теофилакт, изворно вака: “и тој посака да изгради во Охрид свој сопствен манастир. Кон него тој прибави (додаде) и друга црква, којашто отпосле стана архиепископска катедра. И така во Охрид имаше три цркви: една - соборната, и две на св. Климента, коишто по големина беа многу помали од соборната, но со својот кружен и заоблен вид тие се поубави од неа” [Туницкий 1918: 129]. Ова, досега, најадекватно го има образложено Д. Коцо. Тој вели дека двете цркви на Климент се всушност обновената триконхална на источната страна (едната) и доградената, со неправилна правоаголна основа, на западната страна (другата Климентова црква). “Во таков случај втората, прибавена црква би можела да се нарече pronaos на првата, нарочито ако е првата без пронаос, како што е случај со вистинската Климентова црква”. Оттука и гробот на Светителот "во пронаосот” има точна местоположба. Втората црква нема кружна и заоблена форма (“колцест и валчест вид”, како што преведува Д. Коцо), но бидејќи двете цркви, всушност, претставувале “една маса”, тие изгледале, со својата форма, поубави од соборната [Коцо 1948: 179-180]. Ова толкување на Д. Коцо се́ уште не е надминато, но должни сме да укажеме на една археолошка ситуација која е евидентирана со поновите систематски археолошки истражувања при реализацијата на проектот “Возобновување на комплексот 'Светиклиментов универзитет' на Плаошник” во 2008 година, кога во крајниот североисточен агол од Секторот А, во сегашните габаритни граници на локалитетот, “се откри северна апсида од триконхос”. Според извештајот од раководителот на истражувањата во тој дел од локалитетот В. Маленко, јужната апсида од овој објект била уништена од градбите-населба сместена во овој дел на Охрид во доцниот среден век, а источната апсида би требало да се појави со проширување на истражувањата кон исток надвор од границите на 
локалитетот. ${ }^{3}$ Дали се работи за “третата црква”, односно за “втората Светиклиментова црква” која се спомнува кај архиепископот Теофилакт, а која ја изградил св. Климент, се́ уште е хипотетичка претпоставка, помеѓу другото и заради тоа што на овој простор не е најден ни еден фрагмент од живопис, односно, никакви други индиции кои би можеле да се поврзат со значајниот податок.

По префрлувањето на црковното седиште од Преспа во Охрид во почеток на XI век, можеме да констатираме дека тоа е и времето кога Светиклиментовата црква на Плаошник била архитектонски збогатена со егзонартекс и трем од северната страна и со отворен трем од јужната страна [МАлЕнко 2004: 287], како и нејзино живописување на внатрешните Аидни површини.

Во првата половина од XIII век Светиклиментовата црква била разурната, а по нивелирањето на просторот во наосот на местата од четирите столбови биле поставени нови осмоаголни камени базиси, освен на едно место, односно во југоисточниот дел од наосот каде што е гробот на Светителот. Нивелирани биле и просторите од триконхата, северниот трем, нартексот и егзонартексот со тоа што просторот бил исполнет со шут од урнатините и со земја полнатица со дебелина од 0,45 м, а тоа ниво потоа било патосано со под од мермерни плочки со триаголни и четириаголни форми во комбинација со ситни мозаични камчиња. “На sидот помеѓу наосот и нартексот вsидани се два столба со што се добива трибилон од северната страна со мал пиластер, а одјужната се́ уште неиздиференциран проширен пиластер према север за поставување на скалозми во галеријата над нартексот" [МАлЕнко 2004: 288]. Црквата била целосно обновена, се разбира, со мали измени во архитектонскиот склоп, а внатрешноста на sидите површини биле фрескоживописани. Оваа обнова на црквата се случила во времето на охридскиот архиепископ Димитриј Хоматијан (12161236 г.) кога биле поместени и Светиклиментовите посмртни остатоци со интервенција во гробната конструкција (податок што се спомнува во канонот на архиепископот Димитриј Хоматијан) [Пентковский 2013: 91-92] и кога била изработена и над гробот поставена познатата скулптура од дрво на Свети Климент Охридски, зачувана до денес. ${ }^{4}$

Bo XIV век најверојатно биле изградени параклисите, северниот и јужниот, бидејќи истите се прилепени до објектот, а подовите им се на повисоко ниво од другите подови на црквата (Пл. 5). Тогаш најверојатно

3 Извештај за извршените археолошки ископувања во Истражувачкото поле 6 / Плаошник 2007-2008 (В. Маленко - Б. Танески): НУ Завод и Музеј-Охрид.

4 Скулптурата (единствен зачуван споменик изработен во дрво со претстава на Св. Климент од XIII век) денес е изложена во Галеријата на икони-Охрид (комплекс “Света Богородица Перивлепта") и е во надлежност на Националната установа Завод за заштита на спомениците на културата и Музеј-Охрид. 


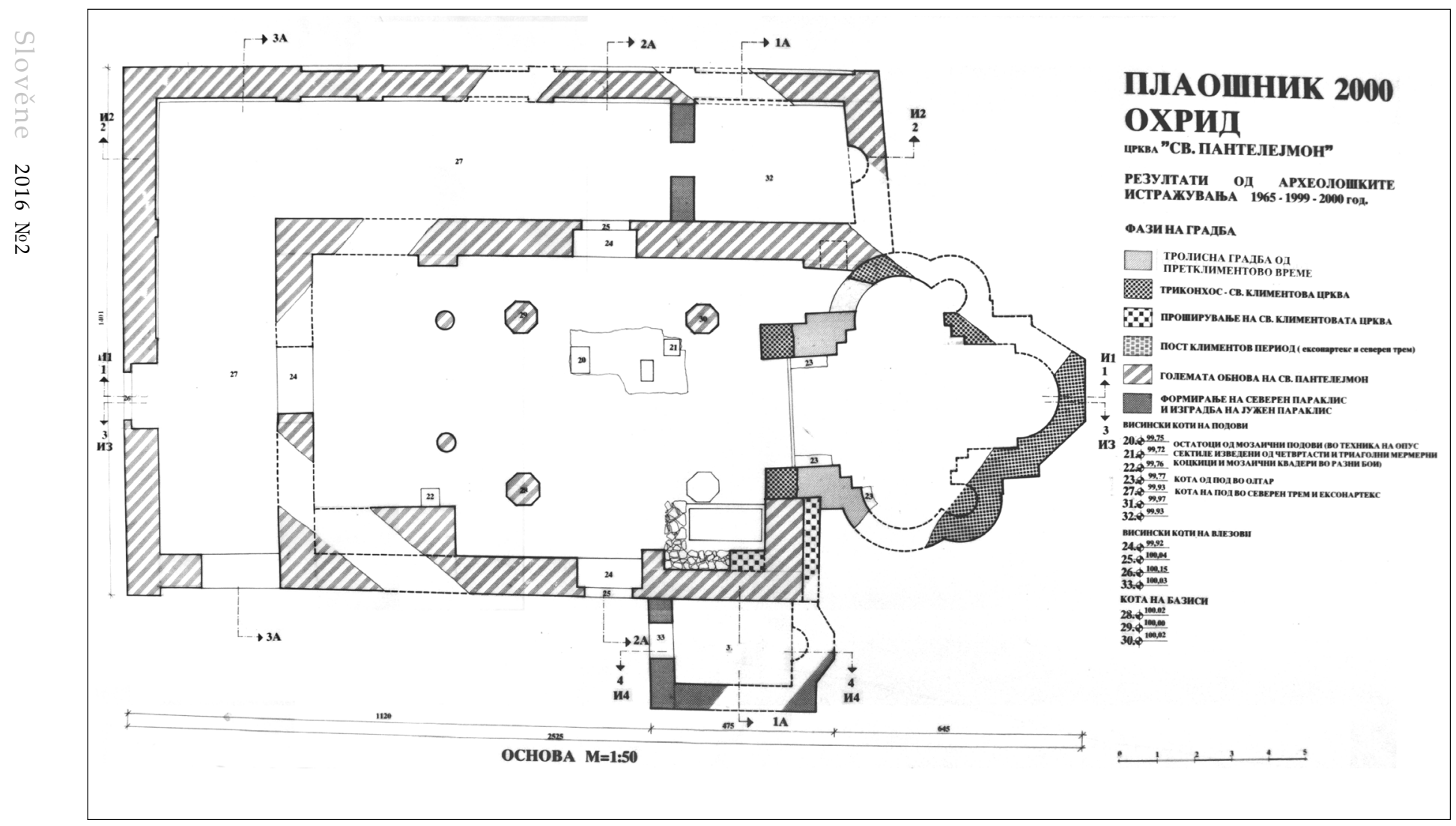

Пл. 5. Светиклиментовата црква по проширувањето во XIV-XV век (цртеж: Тодор и Тања Паскали). 
била изградена и манастирската трпезарија, јужно од јужниот трем на црквата, откриена со ревизионите археолошки истражувања 1999-2002 година [МАленко 2004: 282]. Кон крајот на XIV и во почетокот на XV век, на просторот пред западниот влез во црквата, односно пред егзонартексот, била изградена камбанаријата (Пл. 6), а некое време подоцна, биле затворени влезовите во камбанаријата: северниот и јужниот, како и влезот во јужниот трем [IBID.].

Кон крајот XV век (1490-1491 г.) Светиклиментовиот манастир со црквата и конаците бил разрушен од османлиската власт во Охрид. ${ }^{5}$ По хронолошкиот ред на работите, според Д. Коцо, “светиклиментовата црква како џамија” била урната во втората половина на XVI век, а во првата половина на XVII век, преку урнатините била изградена Синан Челеби џамијата, односно Султан Мехмед џамијата ${ }^{6}$ (Пл. 7).

Плаошничката почва има исклучително комплексна фунерарна ситуација за цивилизациите кои егзистирале на овој простор, но во религиска и стратиграфска смисла овозможува поткрепа и потврда на многубројни недоволно јасни археолошки ситуации. Стратиграфската поставеност, ориентацијата на гробовите, архитектонските карактеристики на гробните конструкции, личните предмети на покојниците или другите прилози (дарови) поставени на соодветни места во гробната јама, сите тие околности обезбедуваат незаобиколни факти (материјални, опипливи, непобитни). Во досегашните археолошки кампањи на Плаошник се откриени и документирани 4253 гробови, гробни конструкции и разни видови групации на остеолошки содржини (зависно од пристапот, обичаите на популациите и времето во кое живееле). Во текот на

5 Според Д. Коцо, Светиклиментовата црква во ова време не била урната, туку била претворена во џамија (1466 година) и таа егзистирала како таква (со обsир на тенкиот слој од вар на некои фрагменти од фрески најдени во слоевите под подот од сегашната џамија) до првите децении на XVI век, а до крајот на првата половина од XVI век, кога условите во османлиската империја биле поблагопријатни за христијанските поданици, била обновувана повторно како Светиклиментова црква, поточно во времето на архиепископот Прохор, на што укажува откритието при археолошките истражувања во 1965/1966 година, кога е откриена уште една апсида меѓу апсидата од Светиклиментовиот триконхос (за 1,20 м источно од неа) и апсидата од тробродната ранохристијанска базилика (за 4,00 м западно од неа), свртена кон исток, како и другите две апсиди од христијанските објекти. Во 1966 година биле откриени и остатоци од полукружен sид северно од североисточниот агол на џамијата, што дава за право да се претпостави дека и таа обновена црква имала триконхална форма [Коцо 1967A: 245-255]. Во прилог на тоа одат и новооткриените калуѓерски гробови во слојот од турскиот период, над урнатата “црква како џамија” кои се ориентирани истокзапад, исто како и трите апсиди од црквите.

6 Според Д. Коцо, тогаш биле пренесени во црквата Св. Богородица Перивлепта моштите на Св. Климент и надгробната плоча со два словенски натписи: едниот со податок за смртта на Св. Климент, а другиот со годината на смртта на архиепископот Прохор, кои биле зачувани во обновената Светиклиментова црква од XVI век [Коцо 1967А: 251-252, 255]. 


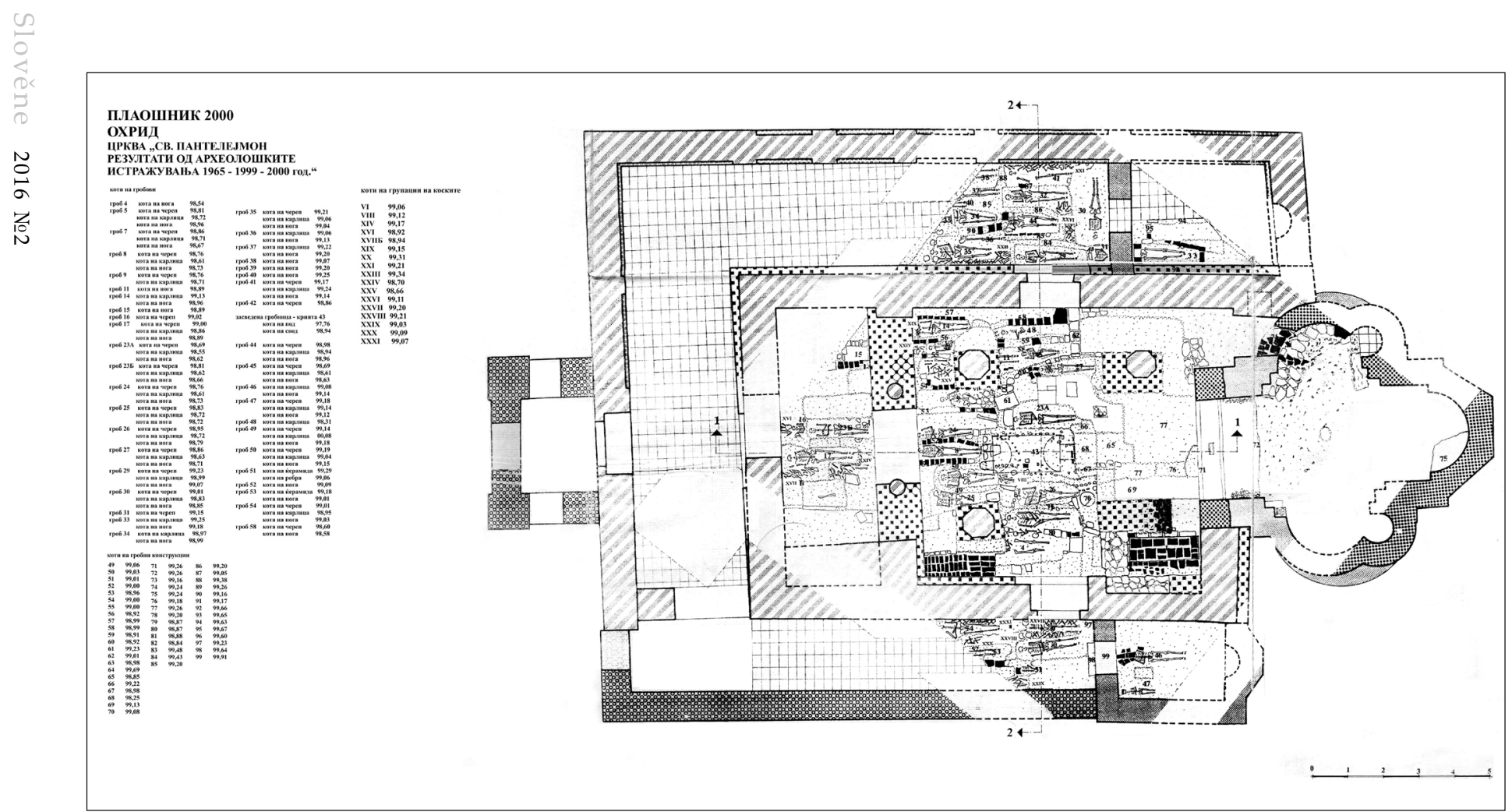

Пл. 6. Светиклиментовата црква кон крајот на XIV век (цртеж: Тодор и Тања Паскали). 


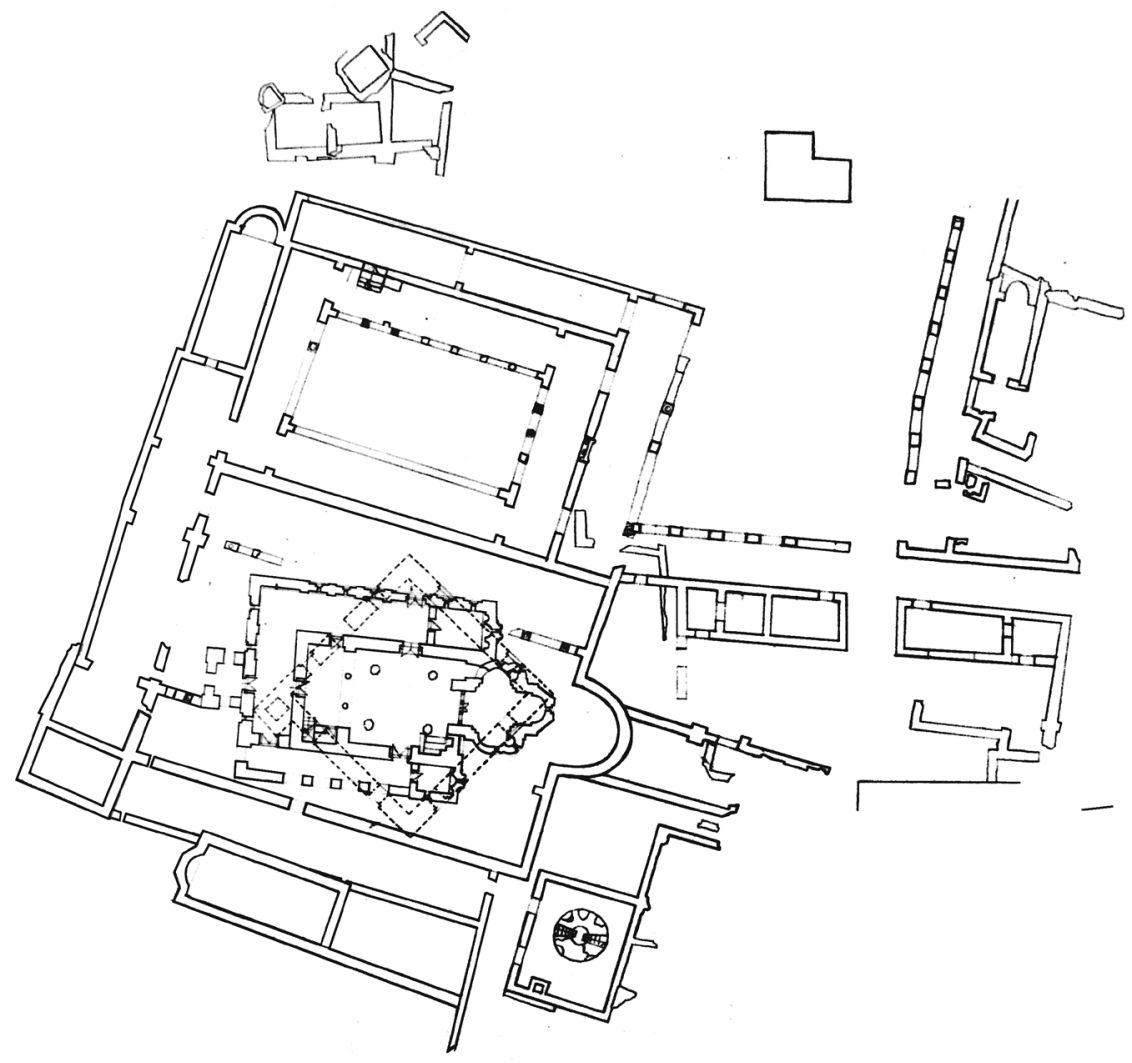

Пл. 7. Ранохристијанска базилика,

Светиклиментова црква, Султан Мехмед џамија

(цртеж: Тодор и Тања Паскали).

истражувачките зафати во внатрешноста на Светиклиментовата црква, откриени се повеќе гробови, гробни групации и стратиграфски гробни ситуации, како и една поголема засведена гробница-крипта во источната половина од наосот. Во гробовите кои се вкопани во централниот дел од внатрешноста на црквата (наос) и во придружниот западен дел (нартекс) биле погребувани свештени лица, додека во гробовите откриени во северниот дел од црквата биле погребувани и цивилни луѓе од побогатите охридски слоеви (Пл. 6). Најзначаен од сите овие гробови е, секако, веќе спомнуваниот, гроб на Св. Климент, којшто, како што се знае, светителот си го изградил уште додека бил жив и во кого бил погребен по неговата смрт во 916 година. Во откриените гробови во црквата најдени се многубројни прилози (бронзени и сребрени монети, накит, 
керамички фрагменти и цели садови), меѓу кои и шест бронзени крстови-реликвијари. ${ }^{7}$ Крстовите се најдени во непосредна близина на Светиклиментовиот гроб, западно од него, собрани на едно место во гробната јама од гробот број 5 (веројатно припаѓале на претходното погребување). Тие се двојни крстови (на преклоп) во чија празнина, меѓу предната и задната страна, се ставало дел од чесно дрво (реликвија). Крстовите и на предната (аверс) и на задната (реверс) страна, се богато украсени со релјефни претстави на Исус Христос распнат и Св. Јован Крстител (кај два крста, предната страна) и со Богородица Оранта (со кренати раце во став на молитва) кај пет крстови (задната страна). Задната страна (реверс) на еден од

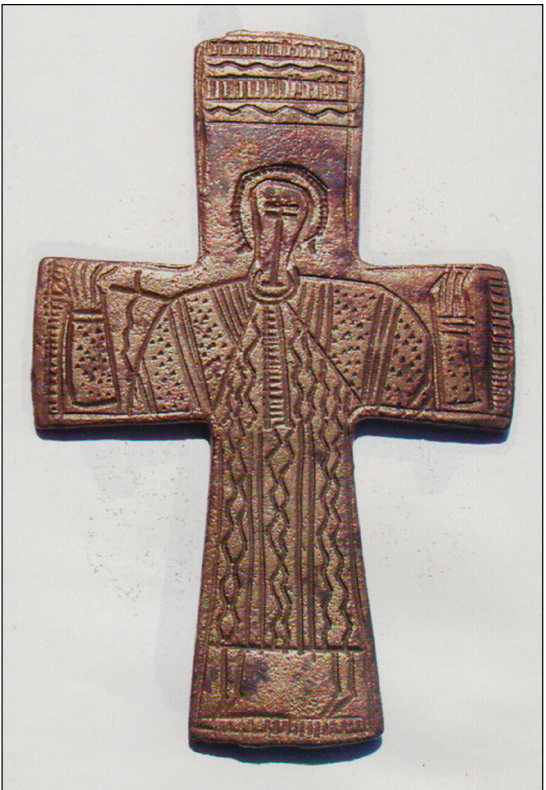

Сл. 4. Двоен пекторален крстреликвијар (реверс), XI век. крстовите е украсена со релјефна претстава на еден светител со кренати раце во став на молитва и со богато украсена архиерејска одежда. Не е исклучено дека можеби се работи за претстава на Св. Климент Охридски. Ваквите крстови-реликвијари се употребувале во времето од Х до XII век ([ПочучА КузмАн 2000], Сл. 4).

Натака, потребно е да се осврнеме само уште на две значајни археолошки ситуации, главно констатирани и документирани со најновите археолошки истражувања. Имено, со овие истражувања на повеќе пунктови на локалитетот беа констатирани концентрирана појава на фрагменти од фрескоживопис, а на некои од нив и архитектонски остатоци од средновековни сакрални објекти-цркви, сите во релативно непосредна близина на Светиклиментовата црква и тетраконхалниот сакрален објект (Пл. 8). Станува збор за архитектонски остатоци од средновековна црква и многубројна концентрација на фрагменти од живопис на просторот за стотина метра југозападно од црквата на Св. Климент и Св. Пантелејмон (Истражувачко поле 4), потоа, слична ситуација, но со уште поголема концентрација на просторот непосредно јужно до придружните објекти на Светиклиментовата црква и ранохристијанската базилика, како и многубројни фрески закопани во поголема јама непосредно

7 Инв. бр. од ЗМОА-9325 до ЗМОА-9330 (Завод и Музеј-Охрид). 


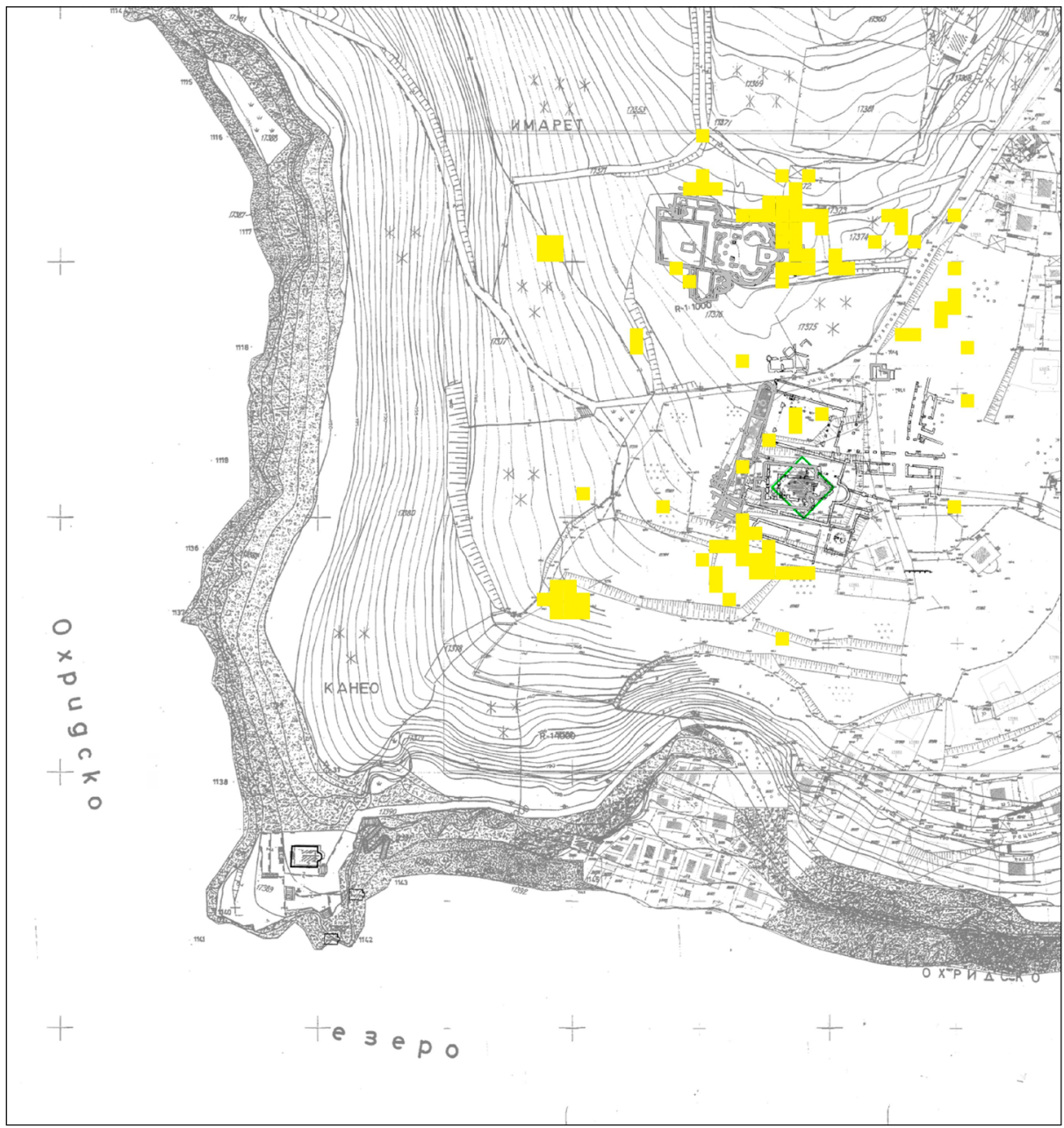

Пл. 8. Плаошник, Пунктови со концентрација на фрагментирани фрески.

северно до црквата, односно во атриумот од ранохристијанската базилика, за кои, тие јужно (Истражувачко поле 3) можеме да кажеме дека припаѓаат на Светиклиментовата црква (XIII век, трпезарија) и северно, во атриумот (Истражувачко поле 2), на ранохристијанската базилика (V-VI век), а ова особено и заради фактот што во јамата со фрески северно од Св. Климентовата црква беа откриени и други археолошки предмети со хронолошка припадност на доцната антика и раното христијанство (керамика, монети). Во средновековните слоеви источно до поликохалната ранохристијанска црква, на поширок простор, констатирана 
е ваква ситуација со концентрација на фрагменти од фрески, а тоа заради фактот што до средината на минатиот век на тој простор имало остатоци од помала средновековна црква и дека тие фрагменти припаѓале на тој објект ${ }^{8}$. Исто така, со најновите археолошки зафати, такви пунктови, но со помали размери, се констатирани на просторите источно меѓу комплексот Светиклиментова црква и комплексот ранохристијанска поликонхална црква (Истражувачко поле 5), како и западно меѓу двата комплекса (Истражувачко поле 6), особено западно од атриумот на поликонхосот за триесеттина метри каде што се констатирани и апсидални остатоци од средновековен сакрален објект.

Интересно е да се констатира дека истражувачите, особено Д. Коцо во статија од 1948 година, често го спомнуваат “Светиклиментовиот манастир”, мислејќи на црквата како најсвет дел од манастирот, на црквата како манастир, подразбирајќи дека целиот манастирски комплекс, заедно со манастирските конаци, секако постоел, иако не знаеме точно на кој дел од комплексот се наоѓале конаците. Тоа се повторува од Теофилакта навака кој вели дека Светиклиментовото тело “било погребено во истиот манастир”, но потоа објаснува во кој дел од храмот (манастирски) било тоа вечно почивалиште. "Манастирот” и “манастирската црква” не е едно сосем исто, туку во нашиот случај црквата е значајна сама по себе поради тоа што во неа се наоѓа гробот на Светителот, а манастирот, односно манастирските конаци поради фактот што во нив, веројатно, се случувала мисијата на Светиклиментовата школа. Светиклиментовиот манастир како комплексна целина (во остатоци) се оформи со систематските археолошки истражувања во 2007-2008 г. кога фрагментарно, на некои делови јужно од црквата беа констатирани остатоци од градби кои би можеле да бидат конаци и простории во рамките на манастирскиот комплекс. Во оваа смисла посигурна е состојбата со архитектонските остатоци во југозападниот и западниот дел од локалитетот, односно недалеку од монументалната тробродна базилика и недалеку западно од Светиклиментовата црква. Таму се откриени остатоци од поврзани правоаголни простории формирани со ьидови од камен и кал на кои темелните партии им се фундирани на нестабилна ровка земја. Сидовите се широки 0,70-0,80 м, зачувани до висина од 1,00-1,20 м. На археолошките планови остатоците се означени (во Истражувачко поле 2) како објект D, просторија 1-5, 6 и ба (Пл. 9). Дека се работи за остатоци од манастирски конаци на Светиклиментовиот манастир говорат и закопаните “манастирски богатства”, поточно откриените депоа на монети, закопани во темелите покрај нивните западни sидови: депото со 1383 венецијански сребрени монети од XIII и XIV век зачувани во керамичен

8 Констатирано со постарите истражувачки зафати во 1959-1967 г. 


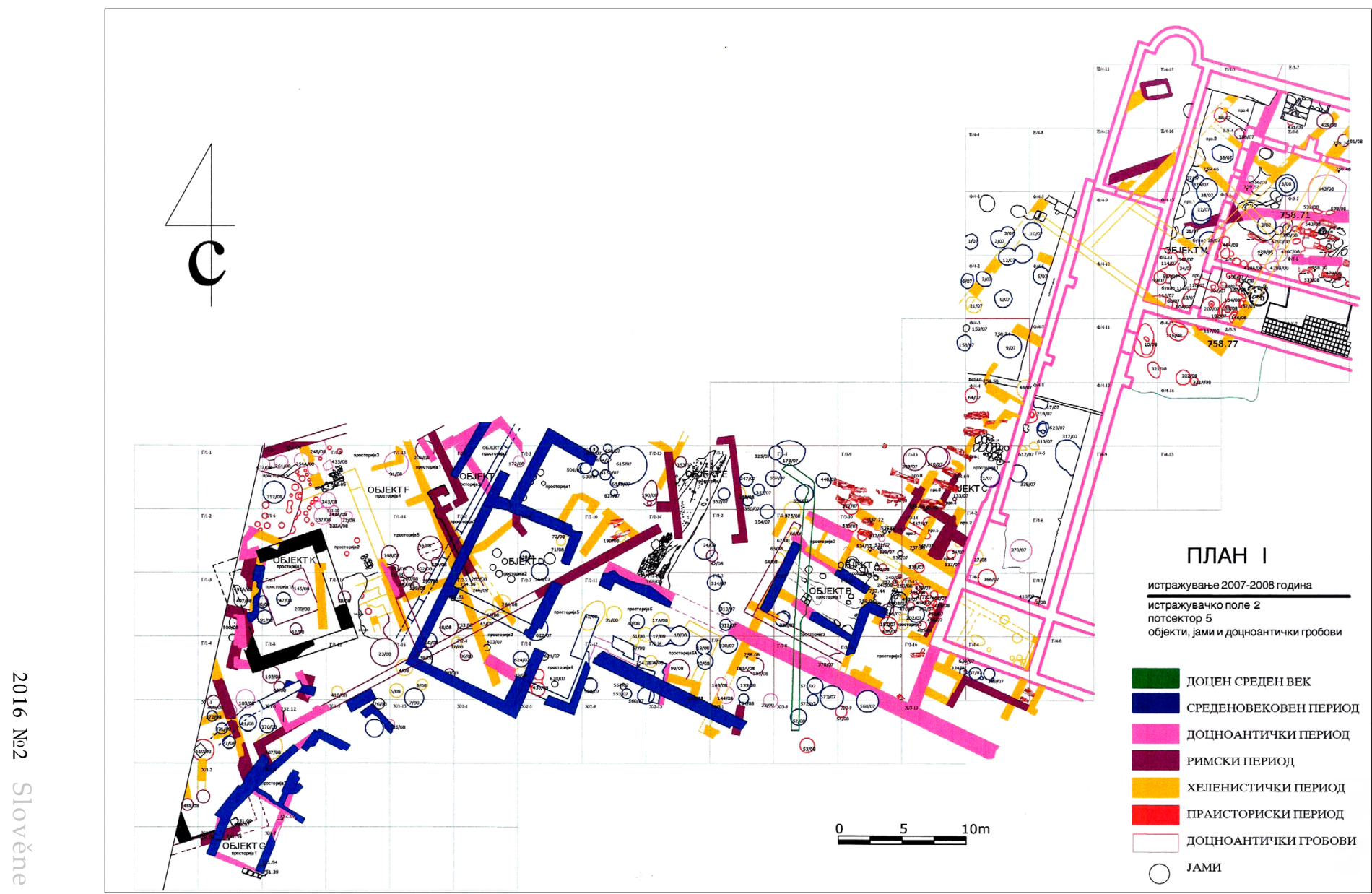

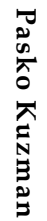

Пл. 9. Остатоците од Светиклиментовите манастирски конаци (објект D, простории 1 - 6а) (дигитал.: Горан Панчев). 
сад (Сл. 5) и депото од 2787 бронзени трахеи зачувани во тканина (најверојатно вреќа) главно од XIII век (Сл. 6). Ова се, значи, архитектонските остатоци од манастирските конаци кои најверојатно првобитно биле подигнати во Светиклиментовото време, а се одржале до времето на Отоманската доминација на овие простори. Тие биле обновувани и во времето на архиепископот Григориј (прва половина на XIV век), кога го добиле и името “Манастир на Св. Климент” [Пентковский 2013: 96]. Само со нивната археолошка идентификација можеме да го именуваме овој комплекс со името “Светиклиментов манастир”, што истовремено значи и Светиклиментова школа (Сл. 7).

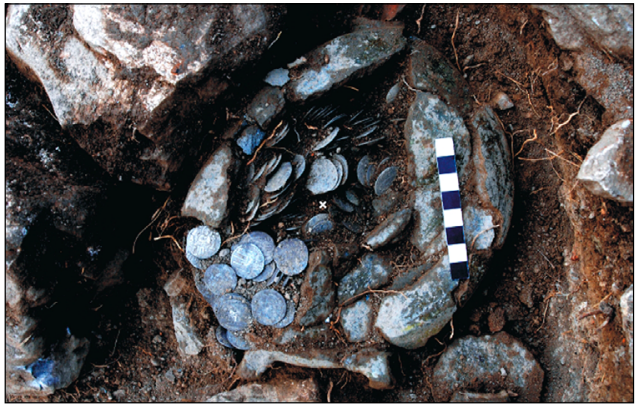

Сл. 5. Депо со венецијански монети под темел од манастирски конак.

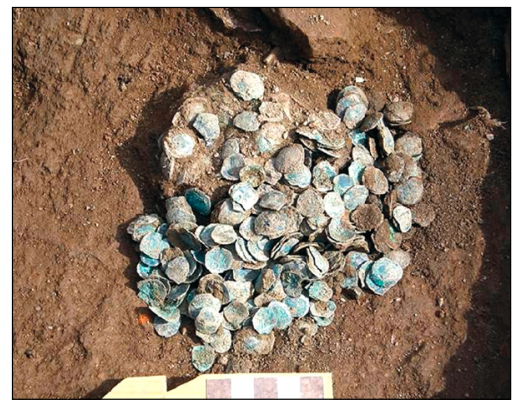

Сл. 6. Депо на трахеи под темел од манастирски конак.

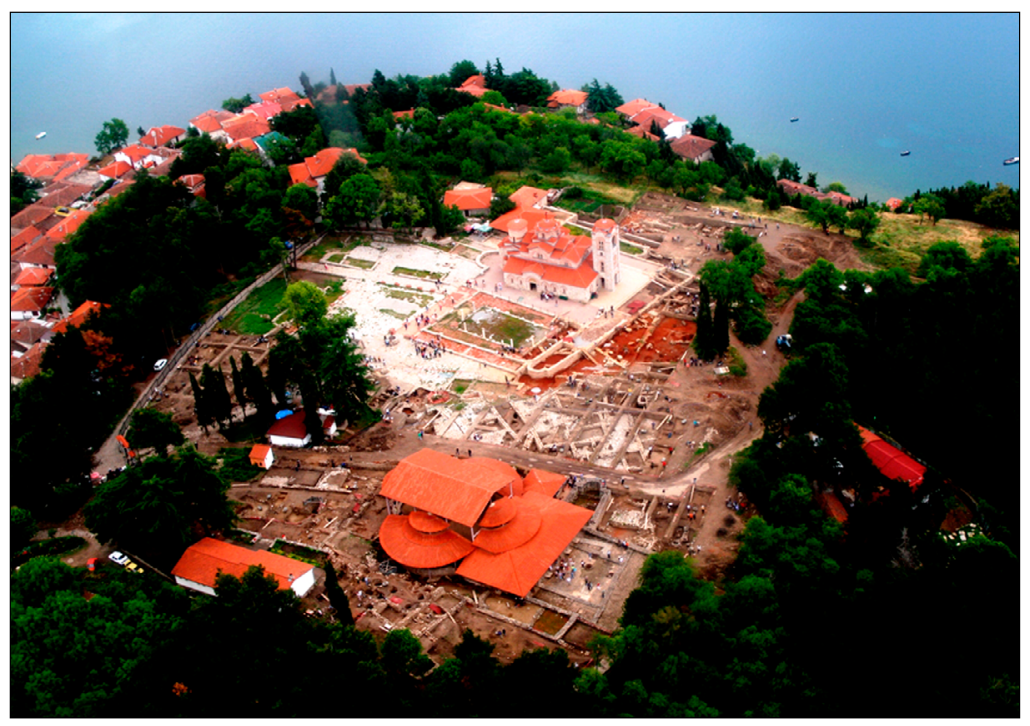

Сл. 7. Плаошник по археолошките истражувања (2012 г.). 


\section{Свети Наум / Св. Архангели}

Што се однесува до другите археолошки податоци за сакралната архитектура од Климентовото време во Охридскиот регион, времето кое го означува најстарото градителско наследство на христијанизираните Словени, поточно за триконхалните цркви од ова време, мора да му се верува и натаму “на научните поставки од Д. Коцо, дека тие биле вкоренувани во македонската средновековна архитектура особено со Климентовиот обновен триконхос и новоизградениот на Наум врз бреговите на Охридското Езеро” [Миљковиќ-ПЕПЕк 1986: 232]. Содружникот и “собратот” на свети Климент од времето на Моравската мисија, свети Наум доаѓа во Кутмичевица и Охрид да му помогне на Свети Климент во неговата мисија. Во почетокот на Х век тој ја изградил црквата посветена на Св. Арханѓели над стрмните карпи од јужниот брег на Охридското Езеро. ${ }^{9}$ Во Првото Наумово житие за лоцирањето на црквата стои дека таа била изградена на нсход屯 БҺлаго єзєра, а во Второто житие просторот на манастирот е означен како мєждврєіє (водите од изворите што се вливаат во езерото под манастирот, источно од него и оние води од изворите кај Тушемишта (денес во Албанија) кои исто така се вливаат во езерото) [ИвАнов 1931: 307, 313]. Д. Коцо, во времето од 1950-1955 година извршил детални теоретски истражувања со набљудувања (повремено со мали сондирања во sидните партии) на архитектонските особености на денешниот изглед на црквата од Наумовиот манастир и дошол до заклучоци коишто барале потврда која можела да се обезбеди само со директни археолошки ископувања. Имено, тој заклучил дека денешната црква во Светинаумовиот манастирски комплекс била подигната во османлиско време, но со неговите опсервации успеал да обезбеди индиции кои укажувале на фактот дека истата е надградена над објект од IX-X век, односно над објект кој бил подигнат во Светинаумово време [Коцо 1958: 59-65]. Овој заклучок, главно, бил поинаков од сите дотогашни претпоставки, кои Д. Коцо ги презентира и коментира за архитектонските особености и хронолошката детерминација на Светинаумовата црква. Мислењата на научниците тој ги поделил во две групи: првата група, во која спаѓаат мислењата на В. Григорович, В. Златарски, М. Злоковиќ и Ѓ. Бошковиќ, сметале дека сегашната црква во манастирот ја подигнал Св. Наум во крајот на IX или во почетокот на X век, додека втората група

9 Д. Коцо црквата на Св. Наум ја именува како “Св. Арханѓел” [Коцо 1958: 56], додека другите научници (Ц. Грозданов, П. Миљковиќ-Пепек и др.) како “Св. Арханѓели” [ГроздАнов 1995: 8], што всушност се однесува на “Св. Арханѓел Михаил” (Д. Коцо), или на “Св. Арханѓел Михаил и сите други анѓели” (другите научници). Ова се потврдува и во едниот, па и во другиот случај со именувањето на манастирот во Второто житие на Св. Наум каде што стои дека Наум сътвараєтъ н

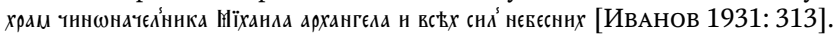



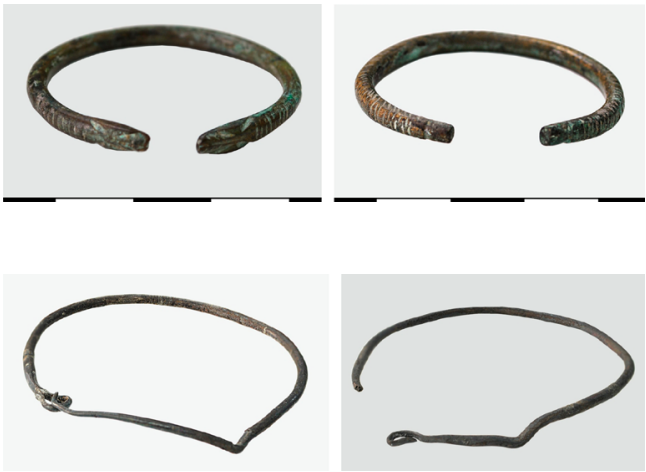

Сл. 8. Св. Наум, Св. Арханѓели, бронзени белегзии.

Сл. 9. Св. Наум, Св. Арханѓели, бронзени наушници.

научници: П. Н. Миљуков, В. Марковиќ, Ј. Иванов и Г. Мије сметале дека сегашната црква била изградена подоцна, односно во XI-XII век (Миљуков) или во XIII-XIV век (другите) [IвID.: 56-58]. За да ги разреши овие дилеми и за да ги потврди индициите и податоците до кои дошол со своите истражувања, Д. Коцо во времето од 6 август до крајот на истиот месец 1955 година и во август (10 дена) 1956 година извршил сондажни археолошки ископувања со кои под денешното ниво од наосот и источната половина на денешната црква со фрагментарно откриени sидни партии утврдил тролисна основа на првобитната црква која ја изградил Св. Наум, архитектонски идентична на Светиклиментовата од Плаошник. Првите две сонди ги поставил покрај јужниот зид од наосот од надворешната, а потоа и од внатрешната страна, за кого претходно утврдил дека тој sид, имајќи ги предвид разликите во опусот на градењето, имал и постара градбена фаза, која била видлива на местото “под денешниот прозорец” [IBID.: 62]. Во сондата покрај надворешната страна од овој sид на наосот, на длабочина од 0,40 м, откриени се најзначајните движни археолошки наоди, односно две бронзени белегзии со дијаметар 3,8 см (Сл. 8), а на длабочина од 0,60 м, за 0,50 м источно од нив, две сребрени наушници со дијаметар од 4,4 см (Сл. 9) [IBID.: 65]. Овие археолошки предмети ${ }^{10}$ се драгоцени податоци затоа што, имајќи ги предвид нивните типолошки карактеристики, како и аналогните појави во блиската околина и пошироко на балканските простори, целосно се вклопуваат во временската рамка на раниот среден век [ЛАхтов 1961: 43, 46].

Светинаумовиот триконхос, имал, како и другите градби со ваков архитектонски склоп, три конхи, северна, јужна и источна, северната и јужната со поголеми димензии од источната, сите сферични од внатрешната страна и правоаголни и аглести од надворешната страна, така што источната била триаголна, додека северната и јужната со прави и

${ }_{10}$ Денес во НУ Завод и Музеј-Охрид, Инв. бр. С-40, С-52, С-62, С-63. 
издолжени sидни партии во правец исток-запад, а исто така и во правец север-југ кај нивните западни страни. Источната триаголна конха формира по еден аголен засек во завршните западни делови од надворешната страна и по два такви засеци на истите делови од внатрешната страна, додека на споевите на конхите, северно и јужно, биле оформени два помали сферични простори - "вдлабнатини со функција на протезис и ѓаконикон” [ГроздАнов 1995: 27]. Во западниот дел од црквата постоел нартекс (наос) кој, според Д. Коцо, комуницирал преку еден тесен простор со јужната конха од старата црква [Коцо 1958: 73, 78] (Пл. 10). Димензиите на олтарниот простор биле речиси истоветни со димензиите на овој простор од Светиклиментовата триконхална црква на Плаошник [ГроздАнов 1995: 27]. Кон хронолошката поткрепа, која е очигледна поради идентичноста со Климентовиот триконхос, овде би го спомнале и податокот кој доаѓа од движната архитектонско-декоративна сфера, а на која укажува С. Радојчиќ во својата анализа на значајните археолошки остатоци на црква-ротонда кај Коњух (Кумановско). Имено, С. Радојчиќ, уште пред истражувањата на Д. Коцо (1950-1955), а во потрага по компаративни елементи за Коњух, укажува на базата од меното во нартексот од црквата во Св. Наум која хронолошки ја детерминира во IX-X век [РАдојчиЋ 1952: 160], на кој факт, како на значаен компаративен податок, укажува и Ц. Грозданов [ГроздАнов 1995: 33].
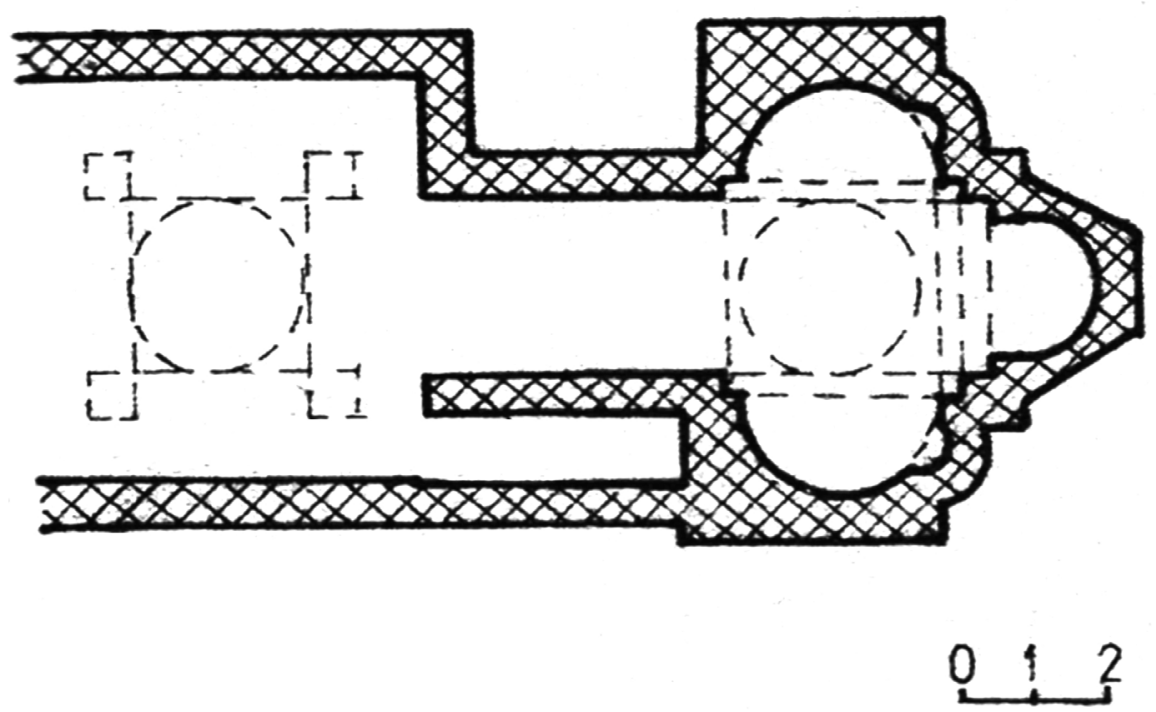

Пл. 10. Св. Арханѓели, манастир Св. Наум (цртеж: Мирка Илоска). 
Во југоисточен дел од нартексот бил откриен и гробот на Св. Наум Охридски вграден во продолжението на јужниот sид од триконхосот кон запад, на место, кое на некој начин, кај Д. Коцо, се совпаѓа со податокот од “Второто житие на св. Наума”, односно вграден “во десното крило на храмот” [Коцо 1958: 76; ИвАнов 1931: 313], што истовремено хронолошки ја детерминира и триконхалната градба. Гробот бил изграден од тули и малтер, имал аркосолиум над главата од покојникот, бил покриен со камени плочи над кои биле поставени тули, а над нив се тулите од сегашниот под на капелата во која денес се наоѓa преместениот Светинаумовиот гроб, веднаш до јужниот sид од сегашната црква. Всушност, првично гробот на Св. Наум бил поставен во сличен простор, како и Светиклиментовиот гроб во црквата на Плаошник. На просторот од капелата се откриени уште три гроба со инхумирани покојници, двата на возрасни, едниот детски, сите без движни гробни наоди во нив. Значи, откако триконхалната црква била до темели урната, при sидањето на новата црква бил изграден нов гроб за Св. Наум близу до јужниот sид од црквата и во него биле преместени скелетните остатоци од првобитниот гроб. Новиот гроб најпрвин “бил во поголем отворен трем со можност за поклонение на повеќе верници, во полуотворен простор спрема двориштето на манастирот" [ГРоздАнов 1995: 31]. Од почит кон светецот и заради заштита на овој фунерарен архитектонски обликуван простор, потоа била изградена и денешната Светинаумова капела.

Сегашната црква во манастирскиот комплекс “Св. Наум”, како што е кажано, била подигната во османлиско време, во две етапи: во првата етапа бил изграден наосот, нартексот и капелата, а во втората куполите над наосот и нартексот. Куполите биле додадени подоцна, односно кога се изградени столбовите во аглите од нартексот, а најстара од нив е куполата изградена над Наумовата капела [Коцо 1958: 79-80].

Со овие археолошко-архитектонски истражувања сосем целосно се докажало дека Светинаумовата црква и Светиклиментовата црква биле речиси идентични по својата основна архитектонска концепција (триконхални), но тие имаат и свои специфики. Бидејќи Светинаумовата црква била изградена на карпеста основа, тоа најверојатно било причина за нејзината архитектонска тенденција да биде триконхална одвнатре, а слободен крст однадвор (правоаголните и аглести форми), за разлика од Светиклиментовата на Плаошник, која е подигната на земјина подлога односно втемелена во земја здравица [Миљковиќ-ПепЕк 1986: 234; ГроздАнов 1995: 27] и која последователно, со нејзиното проширување кон запад била архитектонски осмислена со крстообразна основа (впишан крст на слободни столбови). 
Кога сме веќе во археолошки контекст не е неважно ако спомнеме дека на просторот, односно во полето Љубанишко, испресечено со меѓи и ендеци-канали, меѓу с. Љубаништа и манастирот Св. Наум, на кој простор во водите на езерото се влива малата река Серава, по нивите од жителите на с. Љубаништа, се забележуваат архитектонски фрагменти од стари градби и групации на градбен материјал помешан со градбена керамика. Ова особено во источниот дел од полето, поточно во западното подножје од ридестиот простор на селото, на локалитетот наречен Раица Манастири, по површината од теренот, искористен за бавчи, се гледаат остатоци од урнатини од два поголеми објекта. Во 1971 година, при трасирање на пат кон автокамп на брегот од езерото, од страна на надлежната установа Завод и Музеј-Охрид се извршени заштитни ископувања при кои се откриени темелни партии од ранохристијанска базилика (дел од апсида, јужна конха, дел од sидот на нартексот и засведена гробница), но истовремено се претпостави дека над базиликата била изградена и средновековна црква како и други објекти, можеби во рамки на манастирски комплекс и поголема средновековна населба [МАленко 1978: 341 (3); МАлЕнко, КузМАн 1996: 251]. Имајќи ги предвид овие археолошки индиции, со хронолошки континуитет од античкиот римски период, преку доцноантичките податоци до развиениот и доцниот среден век [МАлЕнко, КУзмАн 1996: 250-251], можеме да кажеме дека овој краезерски Светинаумско-Љубанишки предел, сигурно дека во Светиклиментовата ера и по неа низ вековите имал своевидна значајна улога.

\section{Горица / Охрид}

На источниот брег покрај Охридското Езеро, на околу 3 км југоисточно од Охрид, на самото северно подножје од ридестиот полуостров Горица, при активностите за изградба на воени објекти-касарни на тој простор во 1925 година, биле евидентирани остатоци од темели на триконхална црква (Пл. 11). Според Ѓ. Бошковиќ “оваа црква била решена во облик на збиен триконхос, така да на нестручен набљудувач би можела да му личи и на кружна” [Бошковић 1947: 97]. Основа и пресек на овој триконхос објавиле Ѓ. Бошковиќ и К. Томовски во 1961 година [Bošкović, Toмovsкi 1961: 86] и Д. Коцо во 1966 година [Коцо 1966: 93]. Конхите се полукружни од внатрешната страна (од надворешната е нејасно, заради тоа што сигурно немало археолошко истражување и тој податок останал под земја) и се вели дека претставуваат “збиен триконхос" поради тоа што тие “се приближуваат кон средишниот квадрат” [ГроздАнов 1995: 30], а на завршетоците од конхите, таму 


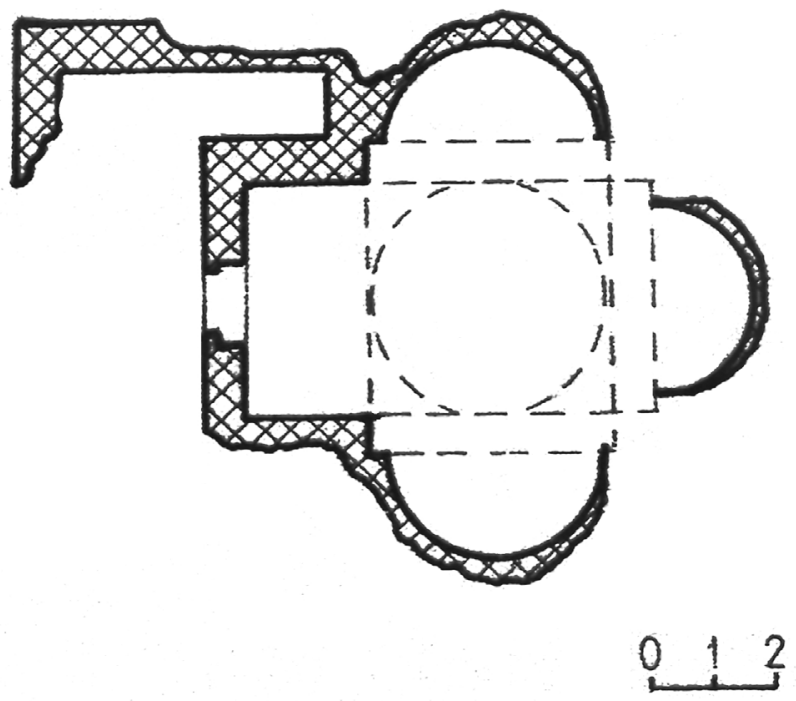

Пл. 11. Горица, Охрид, триконхална црква (цртеж: Мирка Илоска).

каде што се спојуваат меѓусебно, изведени биле правоаголни засеци (кај Д. Коцо). Црквата имала наос кој се состои од поткуполен квадрат, со влез во средишниот дел од западна страна, нартекс и северен трем целосно отворен кон нартексот. Имала купола која била носена “освен од трите конхи (од исток, север и југ) и од три широки арки” [ЧАНЕВАДЕчевскА 1970: 9, 10]. Врз основа на "еден импост капител (со јонско потекло, кај Ѓ. Б.), изваден од езерото, близу до местото на кое се наоѓала градбата, а кој бил 'со архаичен облик', Бошковиќ заклучил дека била изградена во крајот на IX век” [ВАсиљЕвић 1986: 249; БошковиЋ 1947: 97; IDEM 1976: 135]. Н. Чанева-Дечевска, врз основа на архитектонска анализа, хронолошката рамка на оваа црква ја определува во X-XI век [ЧАнЕвА-ДЕчЕвсКА 1970: 10], Ѓ. Стричевиќ го пренесува мислење од К. Петров со нагласка дека не се извршени потребни научни анализи поради што и датацијата е хипотетичка (XI век) [STRIČEvić 1963: 237], а П. Миљковиќ-Пепек, презентирајќи ја основата на црквата, хронолошки ја сместува во IX-XI век [МиљковиќПЕпек 1986: 229]. Инаку, од Горица потекнува и една надгробна ара со вклесан грчки натпис која најверојатно потекнува од простор со пагански архитектонски содржини (храм со надгробен споменик) врз кои архитектонски остатоци, не ретко, заради светоста, се граделе и христијански храмови [Вулић 1934: 22-23 (50-51), 44]. 


\section{Злести / Св. Богородица Пречиста-Раштани}

Во летото 1936 година српскиот научник Милан Кашанин прв ги видел и ги евидентирал архитектонските остатоци на триконхалната црква во близина на селото Злести во областа Долна Дебарца, “на патот за Кичево, во шумичка, околу 30 км од Охрид”, ${ }^{11}$ на околу 2 км јужно од патот ЗлестиБотун, на блага падина во северните пазуви од планинскиот масив што се протега во правец запад-исток, ${ }^{12}$ кога и ги забележал на самиот локалитет најбитните елементи кои во тој момент ги воочил: “Олтарска апсида и певнички апсиди полукружни однадвор и одвнатре. Чудни ќошови. Да се пише на Секцијата во Охрид да ја снимат основата. Sидано со камен. Антички меѓупрозорници". ${ }^{13}$ Во своите белешки М. Кашанин уште и соопштува дека “околу црквата се наоѓаат и повеќе делови од фрагментирани столбови и капители со врежани мали волути", како и една камена надгробна плоча (со димензии: должина 1,85 м; ширина 0,75 м); плочата (Сл. 10) се наоѓала во средината на црквата и на неа се “забележувала трага која била нанесена од рингла на некоја врата и отвор во кого ринглата се вглавувала во каменот" што пак значи дека истата претходно била

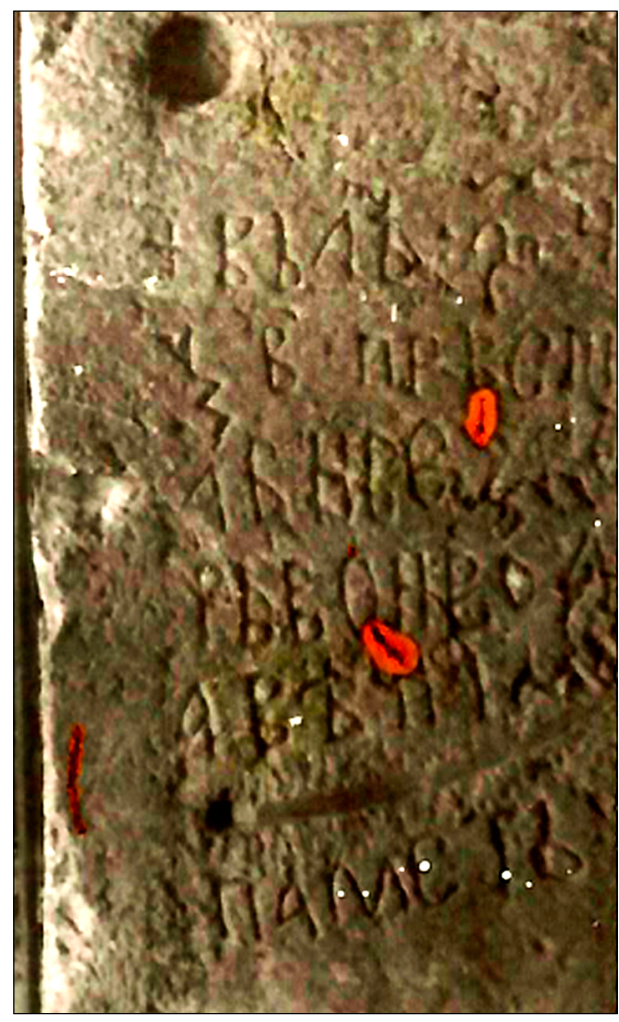

Сл. 10. Злести, триконхос, камена плоча со словенски натпис от 1454 г.

11 Забелешките од М. Кашанин кои се однесуваат на триконхалната црква во близина на с. Злести, Охридско, денес се чуваат во Народниот музеј во Белград (Заоставштина на Милан Кашанин, Архивска кутија, бр. 2, 1/18/1-6). Ги публикувал Драгослав Б. Васиљевиќ, кој ги проширил и доразработил Кашаниновите сфаќања за споменикот [ВАсиљЕВић 1986].

12 Целиот овој планински простор го носи топонимот Раштани, а во средниот век егзистирало истоимено село чии жители под притисок на турските зулуми се иселиле во кичевската околина.

${ }_{13}$ Народен музеј во Белград, Заоставштина на Милан Кашанин, Архивска кутија, бр. $2,1 / 18 / 1$ r. 


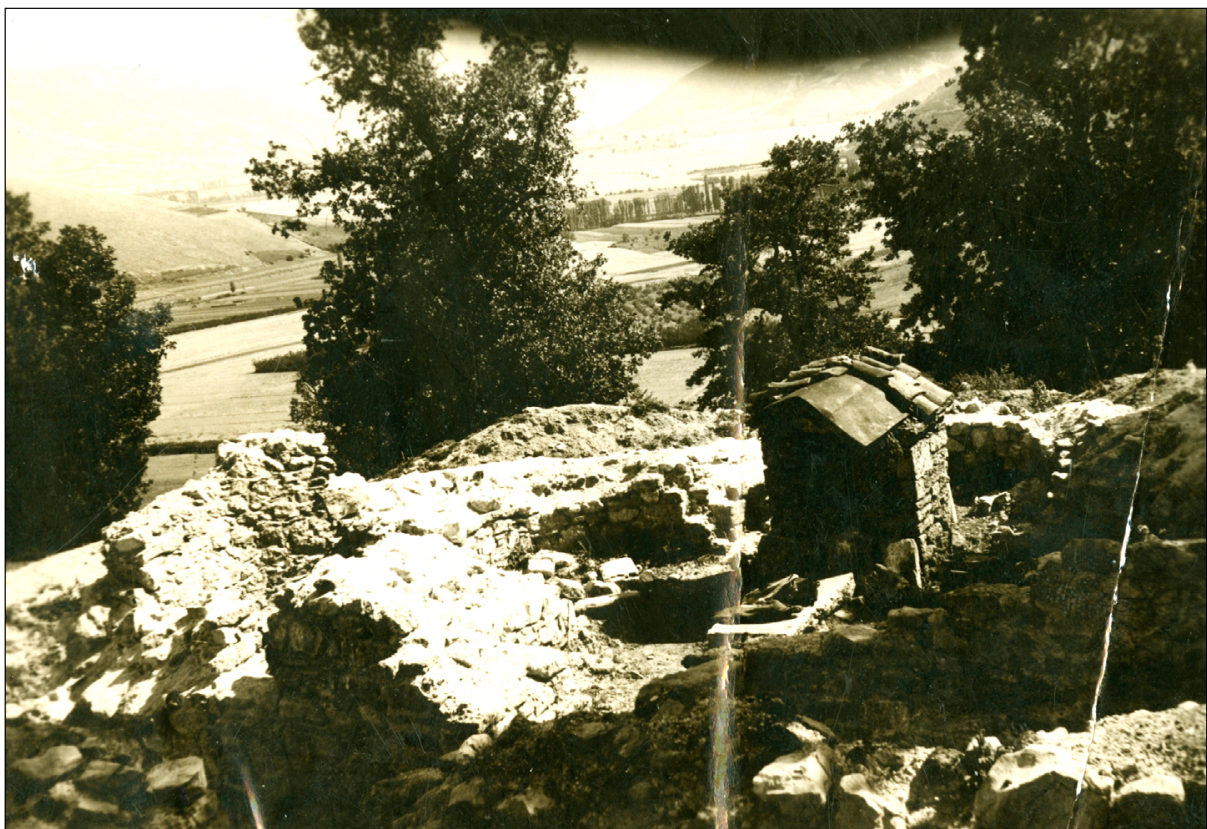

Сл. 11. Злести, триконхос (фото 1937 г.).

на некое друго место. ${ }^{14}$ Плочата била пренесена во музејските простории во Охрид и подоцна мистериозно изгубена, но, за среќа, постојат сликата и изработената копија од гипс. На оваа плоча бил врежан натпис од

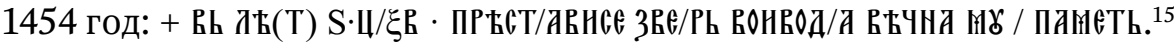

Освен забелешките со податоци, М. Кашанин се погрижил преку тогашните охридски надлежни служби да обезбеди и една фотографија од остатоците на црквата (Сл. 11), ${ }^{16}$ како и архитектонски цртеж на основата од црквата (Пл. 12), кој бил изработен од охридскиот архитект П. Радосављевиќ. ${ }^{17}$ Од нацртаната основа се гледа дека меѓу трите апсиди и западниот травеј функционирал средишен квадратен простор отворен кон апсидалните простори и кон запад со своја должина од 3,20 м.

14 Народен музеј во Белград, Заоставштина на Милан Кашанин, Архивска кутија, бр. $2,1 / 18 / 4$.

15 Народен музеј во Белград, Заоставштина на Милан Кашанин, Архивска кутија, бр. $2,1 / 18 / 1$ v. Читање и датирање на натписот од М. Кашанин [ВАсиљЕВић 1986: 244] е погрешно.

16 Народен музеј во Белград, Заоставштина на Милан Кашанин, Архивска кутија, бр. $2,1 / 18 / 5$.

17 Народен музеј во Белград, Заоставштина на Милан Кашанин, Архивска кутија, бр. $2,1 / 18 / 6$. 


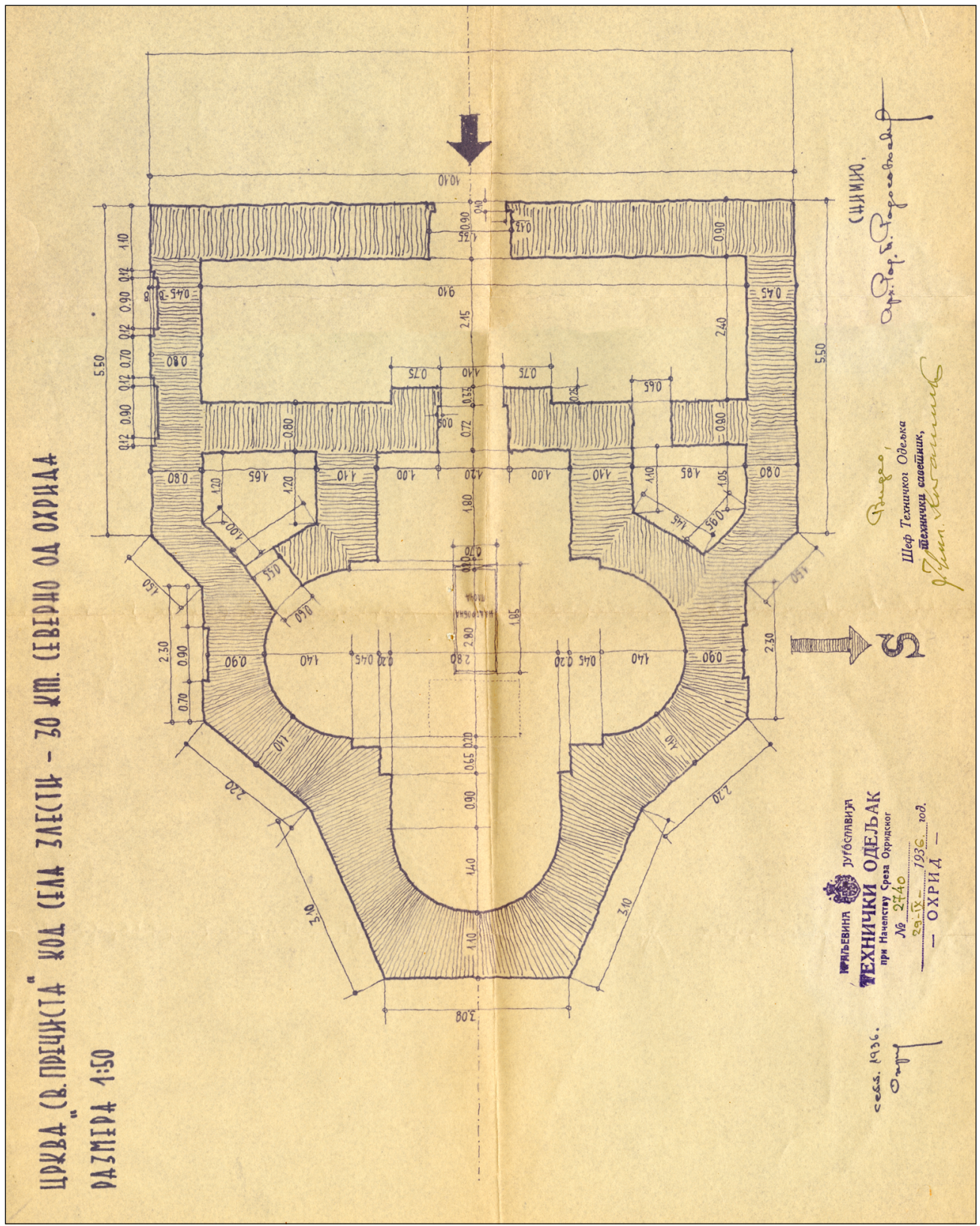

Пл. 12. Злести, Охридско, основа на триконхална црква (П. Радосављевиќ). Народен музеј во Белград, Заоставштина на Милан Кашанин, Архивска кутија, бр. 2, 1/18/6. 
Аглите на квадратот биле добиени со спојувањето на апсидите со бочните sидови од западниот травеј на наосот и со споевите на апсидите на источната страна. Слично решение на средишниот простор имаме кај Светиклиментовиот триконхос на Плаошник и кај триконхосот во Горица-Охрид [ВАсиљЕВић 1986: 250]. Источната апсида е подолга за 0,90 м со што е обезбеден простор за поставување на чесна трпеза и вршење на богослужба, додека другите две апсиди (северната и јужната) имаат еднакви димензии на внатрешниот простор (полупречник 1,40 м). "Средишниот простор бил покриен со купола на што укажуваат sидовите од апсидите и бочните sидови од западниот травеј широки 1,10 м”, а била наслонета на лаковите од апсидите со ширина 0,45 м (од северната и јужната апсида) и 0,65 м (од источната апсида), “на западната страна куполата морала да биде наслонета на полусферичниот свод од западниот травеј” [IBID.: 251]. Црквата имала нартекс со влез во средишниот дел од западната страна, како и со влез во наосот, исто така во средишниот дел од источниот sид на нартексот. Зидовите од нартексот од северната и јужната страна се продолжени во нивните источни делови и на должина од 5,50 м косо свртуваат кон внатре затворајќи така простори северно и јужно од западниот травеј, односно северозападно од северната и југозападно од јужната конха. Така се формирани две петострани простории (анекси), јужната со малку помали димензии од северната. Во северната просторија се влегувало од нартексот, а во јужната од јужната апсида. Д. Васиљевиќ укажува дека ваква архитектонска ситуација имаме и кај триконхосот во Горица-Охрид од северната страна, северно од западниот травеј која била отворена кон нартексот, како и кај црквата Свети Никола во Дечани каде што постоела таква просторија од јужната страна, а се влегувало во неа од јужната апсида, како и во Злести [IBID.: 251]. Натака, се укажува и на фактот дека нартексот и централниот дел на црквата биле изградени истовремено, имајќи ги предвид двете плитки ниши изведени на јужната фасада од нартексот, односно источната која со својата ширина ги поврзува јужните зидови од наосот и нартексот [IBID.: $250]$, а исто така и двете бочни петоаголни простории (анекси) ја имаат хомогеноста со целата архитектонска градба.

Всушност, ова покажува дека актуелната триконхална црква била изградена во еден градежен зафат, според досегашните анализи на постарите истражувачи, наспроти некои наши подоцнежни теренски согледувања (дилетации кај некои делови од sидовите на анексите) со кои се претпоставува дополнителни градежни интервенции на тие архитектонски делови од градбата. Трите конхи од внатрешната страна се полукружни, а од надворешната тристрани (источната) и двострани (северната и јужната, заради зафатеноста на “третата страна” со архитектонскиот склоп на анексите). Најголемата должина на црквата (исток-запад) изне- 


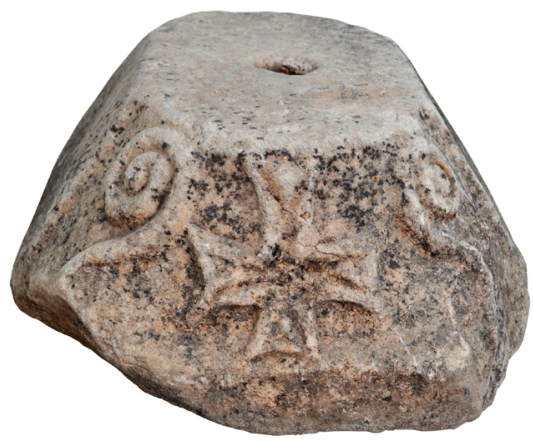

Сл. 12. Злести, импост капител.

сува 17 м, а најголемата ширина 9 м. Градена е од кршен камен и варов малтер, а на одделни места со тули и малтер. Ширината на sидовите изнесува $0,90 \mathrm{~m}$, а најголемата зачуваност е 2,0 м височина и тоа на северниот анекс.

Како што главно забележал и M. Кашанин, по зидовите и во внатрешноста на објектот се поместени повеќе мермерни меноа, базиси и капители со орнаменти (еден од нив е импост капител со релјефно изработен крст на предната страна со јонски волути лево и десно од крстот, ${ }^{18}$ Сл. 12), фрагменти од столбови, мермерен праг - сите употребени како сполии. Меѓу нив е и една ара со грчки натпис кој е нечитлив поради уништеност ${ }^{19}$ (Сл. 13). Некои од овие податоци укажуваат на тоа дека овој триконхос најверојатно бил подигнат врз темели од ранохристијанска базилика, но не се исклучува и можноста на местото првобитно да постоел и храм посветен на некое паганско божество од античкиот период. Југозападно и западно од овој триконхален сакрален објект по површината се видливи поголеми камени плочи од гробни конструкции со ориентација исток-запад [КУЗМАН, МАЛЕНКО 1992: 89-90; МАЛЕНКО, КУЗМАН 1996: 247]. Во овој контекст треба да ја спомнеме и надгробната плоча со словенски натпис

18 Се мисли на импост-капителот кој до неодамна беше сместен во една просторија од новоизградената црква близу триконхосот, кого авторот на овој труд го депонира во НУ Завод и Музеј-Охрид.

19 Оваа ара не е забележана и документирана од М. Кашанин, што можеби говори за тоа дека истата била донесена тука подоцна од некое друго место од околината за да биде зачувана како “свет камен” (чест случај меѓу населението од овие краишта). 
од 1454 година која ја видел и евидентирал М. Кашанин во 1936 година и која не се наоѓала “у свом првобитном положају”, односно со тоа имаме податок дека црквата била во употреба не само во средината од XV век, туку и подоцна.

Имајќи ги предвид сите претпоставки и хронолошките показатели на кои се потпирал М. Кашанин, како и повеќето други истражувачи на триконхосите од Охрид и Охридско (Св. Пантелејмон на Плаошник, Горица, Св. Арханѓели-Св. Наум), Д. Васиљевиќ констатира дека овој триконхос бил изграден во Светиклиментовото време, поточно во времето по 886 година (доаѓањето на свети Климент во Кутмичевица) и пред 916 година (смртта на Св. Климент во Охрид) [ВАСиљЕвић 1986: 252-253]. На предложеното датирање, меѓу другото, укажува и сличноста на покривните керамички плочки од архаичен тип, искористени на триконхалната црква во Злести со покривните керамички плочки искористени на црквата во Асомат (долина на реката Шушица, Јужна Албанија) [XHYHERI ET AL. 2016: 286 (n. 8)], градителство сврзано со дејноста на Св. Климент Охридски и архитектонски план кој се совпаѓa со планот на "пронаосот" во Светиклиментовата црква на Плаошник [МучАй Ет AL. 2014, 18-23].

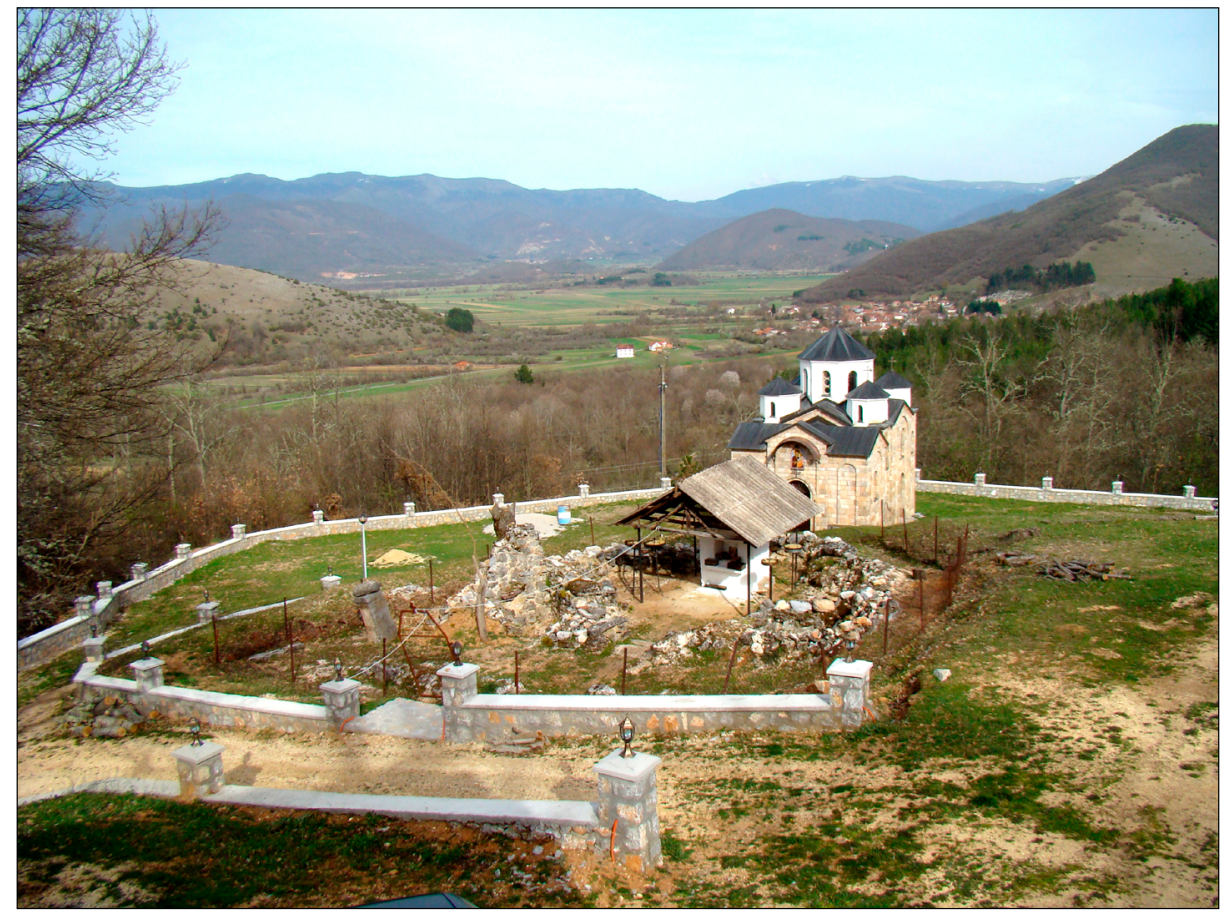

Сл. 14. Злести, триконхална црква Св. Богородица Пречиста (фото 2014 г.). 
Најзначаен заклучок кој всушност следи по исклучително значајните податоци кои се презентирани погоре по заслуга на М. Кашанин уште пред скоро осумдесеттина години, е неотповикливата потреба од систематско археолошко истражување на овој локалитет (Сл. 14) кое, секако, би дало дополнителни многу значајни сознанија за најстариот период на словенското христијанско градителство. ${ }^{20}$

\section{Издеглавје}

Ова старо населено место се наоѓа во областа Горна Дебарца, на околу 40 км северно од Охрид. На околу 2 км северозападно од селото се наоѓa локалитетот Старо Село - Зглавиница, а на ненагласената стрмнина која се спушта кон левиот брег на реката Сатеска евидентирани се остатоци од двоконхална црква која жителите на населбата ја викаат “Св. Никола”. Посеверозападно од оваа црква, на истиот локалитет се наоѓа уште една средновековна црква “Св. Димитриј”. Сегашната црква била подигната во 1928 година врз темели од постара црква ”од која во новата се употребени две меноа". И кај едната и кај другата црква зачувани се камени плочи од стари гробови [КузмАН, МАЛЕнко 1992: 93; МАлЕНко, КузмАн 1996: 248]. Веројатно заради топонимот и податокот за постоење на двоконхалната црква, Д. Коцо во септември 1981 година, со стручна екипа од Завод и Музеј-Охрид, презел сондажни археолошки ископувања. Притоа поставил две сонди, едната јужно од денешната црква Св. Димитрија, а втората северно од олтарната апсида на истата црква. При истражувањата се констатирало дека црквата била изградена врз темели од постара црква. Во една од сондите биле откриени и гробови (два, едниот детски, а другиот од постар покојник), како и движни археолошки предмети, односно обетки “изведени од метален конец” (кај детскиот гроб) и бронзен прстен (во другиот гроб) кои, секако, припаѓале на времето од функционирањето на постарата црква [АнгЕличин-ЖурА 2007: 36-37]. Во западниот дел од селото евидентиран е и археолошки локалитет Манастириште, а во планинскиот предел, јужно од двоконхалната црква се наоѓ уште еден локалитет со топоним Манастир. Таму е расчистен еден помал објект со правоаголна форма (димензии: $4,00 \times 2,30$ м) и со ширина на sидовите од 0,80 м. Градежниот материјал е од делкан камен и бигор. Истражувачите (Д. Коцо)

20 Чудно е и сигурно нема оправдание што досега не се вршени никакви археолошки истражувања на овој локалитет и покрај обидите (секако недоволно упорни) од охридските археолози, посебно од сега веќе пок. Владо Маленко и од авторот на овој труд, кои, можеби и поради “некои околности” не се заложија да ја реализираат една од најзначајните археолошки обврски на оваа македонска територија, како што тоа не го направија ни нивните претходници. Се разбира, во најблиска иднина се надеваме дека ќе биде исправена таа грешка. 


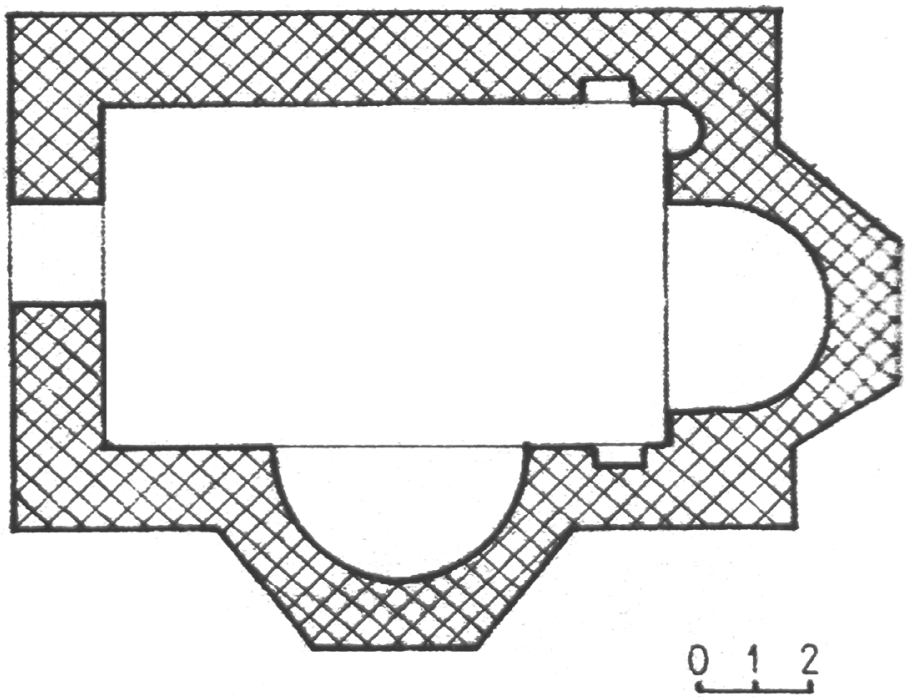

Пл. 13. Издеглавје, Охридско, Св. Никола, основа на двоконхална црква (цртеж: Мирка Илоска).

тогаш сметале дека се работи за манастирски комплекс кој бил во внимание на активностите на Свети Климент [IBID.: 37]. Погоре спомнатата двоконхална црква од Старо Село - Зглавиница во с. Издеглавје археолошки не е соодветно третирана поради што недостасуваат податоци за нејзината комплетна архитектонска концепција. Врз основа на презентираниот план на нејзината основа (Пл. 13), ${ }^{21}$ црквата имала две апсиди, од источната и јужната страна, полукружни од внатрешната, тристрани од надворешната страна и наос со влез од западната страна. Северната страна е целосно затворена со северниот sид, јужната апсида безмалку ја затвора целата јужна страна, а меѓу двете апсиди ги спојува поширока sидна маса. Кај источната апсида, покрај северниот дел од апсидалниот простор има видлив дел од sид со помала ширина кој ја одвојува апсидата од северниот sид на црквата со што постои можност за постоење на параклис.

$* * *$

Целокупното Светиклиментово присуство (книжевни и просветителски и општи културни дострели, архитектонски вредности во рамките на градителството со христијански карактеристики) се потпира на материјални,

21 Архитектонскиот план публикуван: [Миљковиќ-ПЕпек 1986: 229 (14)]. Не успеавме да најдеме кој е авторот на планот. Претпоставуваме дека во соработка со Д. Коцо, автор на планот е К. Томовски. 
културни и духовни фундаменти наталожени од времето на доцнопраисториските, античките и ранохристијанските-рановизантиски цивилизациски достигнувања, што значи имало цврсти темели врз кои можеле да се градат нови вредности. Светиклиментовото присуство и дејност на овие простори е меѓa и врзувачки фактор во континуитетот на егзистирање на цивилизациите пред него и цивилизациите по него. Триконхалните цркви во Охридскиот регион се градени главно по урнекот на Светиклиментовата триконхална црква на Плаошник во Охрид поради големиот углед на светителот и просветителот Свети Климент Охридски, иако Светиклиментовиот триконхос не е сосем оригинална архитектонска градба, туку е само обнова на стар триконхос, кој пак, како христијанска архитектонска форма има подолга традиција не само во рамките на Охридски регион (триконхалната крстилница од ранохристијанската поликонхална црква на Плаошник, триконхалната црква од Лин на западниот брег од Охридското Езеро со хронолошка припадност од првата половина на $V$ век), туку и пошироко на Балканот уште од ранохристијанскиот период [ĆURČIĆ 2010: 153-155, 157-159, 238-243, 322-325].

Движниот археолошки фонд во стратиграфските архиви на плаошничката почва во Светиклиментовиот период (IX-X век) е оскуден за разлика од богатството на движните предмети од сите други периоди кое беше евидентно и документирано во времето на систематските археолошки истражувања. Со најновите археолошки истражувања на Плаошник (2007-2008 г.) беа откриени остатоци од манастирските конаци на Светиклиментовиот манастир во југозападниот и западниот дел од локалитетот, односно недалеку од монументалната тробродна базилика и недалеку западно од Светиклиментовата црква. На истражените простори од локалитетот југозападно од Светиклиментовата црква, западно од поликонхалната црква и источно од неа откриени се архитектонски остатоци и индиции во вид на групации од многубројни фрагменти на фрескоживопис од најмалку четири средновековни цркви (XIII-XIV век) со кои се потврдува фактот дека Плаошник претставувал големо христијанско црковно средиште од ранохристијанскиот до крајот на средновековниот период.

\section{Библиограсрија}

АНГЕЛИЧИН-ЖУРА 2007

АНГЕЛИчИН-ЖУРА Г., Христијански Храмови и свети места во Охридско, Охрид, 2007.

БИТРАКОВА ГРОЗДАНОВА 1975

БИТРАКОВА ГРОЗДАНОВА В., Старохристијански споменици во Охридско, Охрид, 1975. $-2006$

БИТРАКОВА ГРОЗдАНОВА В., “Лихнид во ранохристијанскиот Период и неговото урбано јадро”, во: Јубилеен зборник 25 години митрополит Тимотеј, Охрид, 2006, 257-268. 
174 | The Archaeological Evidences of St. Clement of Ohrid's Activities in Ohrid Region

Бошковић 1947

Бошковић Ђ., Основи средњевековне архитектуре, Београд, 1947. 1976

Бошковић Ђ., Архитектура средњег века, Београд, 1976.

ВАСИљЕВИЋ 1986

ВАСиљЕВит Д., “Триконхос у селу Злести. Прилог Милана Кашанина историји средњовековне архитектуре”, у: Зборник Народног музеја, 12/1: Археологија, Београд, 1986, 243-253.

Вулић 1934

Вулиъ Н., “Антички споменици наше земље”, Споменик Српске краљевске Академије, 77, 1934, 31-84.

ГРОЗДАНОВ 1995

ГроздАНов Ц., Свети Наум Охридски, Скопје, 1995.

ГРОЗДАНОВ ЕТ AL. 2003

ГРОЗДАНОВ Ц., КУЗМАН П., ПАСКАЛИ БУНТАШЕСКА Т., ПЛаошНИК: ВозобНовеНата црква на Св. Климент и Пантелејмон, Охрид, 2003.

ИвАНОв 1931

Иванов Й., Български старини из Македония, София, 1931.

Коцо 1948

Коцо Д., "Климентовиот манастир «Св. Пантелејмон» и раскопката при «Имарет» во Охрид”, Годищен зборник на Философски факултетв во Скопје, 1, 1948, 129-182. 1958

Коцо Д., “Проучавања и археолошки испитувања на црквата на манастирот Св. Наум”, во: Зборник на Археолошкиот музеј: 1957-1958, Скопје, 1958, 56-80.

1966

Коцо Д., “Триконхалните цркви во Климентовото време”, во: Словенска писменост. 1050-годишнина на Климент Охридски, Охрид, 1966, 91-100.

$1967 \mathrm{~A}$

Коцо Д., “Нови податоци за историјата на Климентовиот манастир Св. Пантелејмон во Охрид”, Годишен зборник на Философски факултет во Скопје, 19, 1967, 245-255. 1967ь

Коцо Д., “Археолошки проучувања во Охрид од 1959 до 1965 год”, Годишен зборник на Философски факултет во Скопје, 19, 1967, 257-266.

КУЗМАН 2013

КузмАн П., “Праисториски палафитни населби во Македонија”, во: Македонија: милениумски културно-историски факти, Скопје, 2013, 297-430.

КУЗМАН, МАЛЕНКО 1992

КУЗмАН П., МАлЕНко В., “Преглед на средновековните словенски црковни градби регистрирани како археолошки локалитети во Охридската регија”, во: Светиклиментово слово, Охрид, 1992, 78-95.

ЛАХтов 1961

ЛАхтов В., “Накитот на раносредновековни наоѓалишта во Охрид / Les bijoux des habitats archeologiques datant du haut moyen age dans la region d'Ohrid", во: Зборник на трудови, посебно издание = Recueil de travaux, édition spéciale, Охрид, 1961, 35-70.

МАлЕНКо 1978

МАлЕнко В., “Нови антички наоди во Охрид и Охридско”, во: Жива антика, 28/1-2, Скопје, 1978, 339-349 (1-11). 
2004

МАлЕнко В., “Лихнидско-охридскиот духовен и културен вруток на Плаошник”, во: Македонско-украински културни врски (Х-ХХ век), 2, Скопје, 2004, 279-297.

МАЛЕНКО, КУЗМАН 1988

Маленко В., КузмАн П., “Хермелеја”, во: Лихнид. Зборник на трудови, 6, Охрид, 1988, 89-116.

$-1996$

М<АлЕнко В.>, К<УзмАн П.>, “ХХ. Охрид”, во: Археолошка карта на Република

Македонија, 2, Скопје, 1996, 238-279.

МиљКОвиќ-ПЕПЕк 1986

Миљковиќ-ПепЕк П., "Христијанската архитектура кај Македонските Словени од пред средината на IX век до 1018 година”, во: Климент Охридски. Студии, Скопје, 1986, 225-237.

МучАЙ ЕT AL. 2014

МучАЙ С., ДЖУЕРИ С., РИСтАНИ И., ПЕНтковСКИй А. М., “Средневековые церкви в долине Шушицы (Южная Албания) и славянская епископия свт. Климента Охридского”, Slověne, 1/3, 2014, 5-42.

ПАНОВ 1985

ПАнов Б., “Охрид и Охридско во ранофеудалниот период”, во: Охрид и Охридско низ историјата, 1, Охрид, Скопје, 1985, 173-197.

ПЕНтковСКИй 2013

ПЕнтковский А., “Почитание святителя Климента в Охриде в X-XIV вв.”,

Старобългарска литература, 48, 2013, 79-113.

ПочучА КУзмАн 2000

Почуча Кузман Н., Крстови-реликвијари - каталошка обработка. Истражувања 19992000. Движен археолошки материјал. Плаошник, 2000. Проектна програма (елаборат), Завод за заштита на спомениците на културата и Музеј-Охрид, Охрид, 2000.

ПочУчА КУЗМАН, АцЕСКИ 2008

Почуча КузмАН Н., АцеСКи С., “Крстилница на Плаошник, Охрид”, Македонски археолошки преглед, 1, 2008, 228-232.

ПочучА Кузман ЕT AL. 2008A

ПочУчА КУЗмАН Н., БоцЕВСКА В., АЦЕСКИ С., АНГЕЛИчИН-ЖУРА Г., "Ранохристијанска базилика (нартекс) на Плаошник, Охрид”, Македонски археолошки преглед, 1, 2008, 233-243.

ПочУчА КУЗмАН ET AL. 2008Б

ПочУчА КУЗМАН Н., КАРПУЗОВА С., МишЕВА О., “Плаошник, Охрид”, Македонски археолошки преглед, 1, 2008, 244-250.

РАДОЈЧИЋ 1952

РАдојчић С., “Црква у Коњуху”, Зборник радова Византолошког института, 1, 1952, 148-67.

Туницкий 1918

Туницкий Н. Л., Материалы для истории жизни и деятельности учеников свв. Кирилла и Мефодия, 1: Греческое пространное житие св. Климента Словенского, Сергиев Посад, 1918.

Тутковски 2014

Тутковски М., Ранохристијанските мозаици од Охрид, Скопје, 2014.

ЧАНЕВА-ДЕЧЕВСКА 1970

ЧАНЕвА-ДЕчЕвсКА Н., “Триконхалните църкви от IX-XIV в. по българските земи”, Археология, 4, 1970, 8-21. 
BošKović, ToMovski 1961

BošKović Đ., Томоvsкі К., “Средновековната архитектура во Охрид = L’architecture medievale d'Ohrid”, во: Зборник на трудови, посебно издание = Recueil de travaux, édition spéciale, Охрид, 1961, 71-100.

ĆURČIĆ 2010

ĆURČIĆ S., Architecture in the Balkans from Diocletian to Süleyman the Magnificent, New Haven, 2010.

\section{STRIČEVIĆ 1963}

STRIČEviĆ Đ., "Èglises triconques médiévales en Serbie et en Macédoine et la tradition de l'architecture paléobyzantine", dans: Actes du XII congrès international d'etudies Byzantines, Ochride 10-16 septembre 1961, 1, Beograd, 1963, 224-240.

XHYHERI ET AL. 2016

Xhyheri S., Muçaj S., Pentkovskiy A., Ristani I., "Kërkime arkeologjike në krahinën e Vlorës, Mallakstrës, Myzeqesë dhe Korçës (Korridori Vlorë-Prespë, raport 2013-2015),” Candavia, 6, 2016, 279-314.

\section{Pasko Kuzman}

Institute for Protection of Cultural Monuments and the National Museum, Ohrid, Macedonia

\section{The Archaeological Evidence of St. Clement of Ohrid's Activities in Ohrid Region}

\section{Abstract}

Among the activities of St. Clement of Ohrid was the construction of the church and monastery in Ohrid, which was carried out at the end of the 9th century at the location where some Byzantine basilicas had stood previously. As findings of archaeological excavations have shown, St. Clement first built a small triconch church at the location of the ruined basilica. This triconchos was later expanded by the addition of a capacious "pronaos" in inscribed-cross form, where St. Clement was interred. This "pronaos" was characterized by entrances on the north and south sides that were identical to those of the inscribed-cross church that existed near the village of Velcë along the Šušica River (in southern Albania) at the turn of the 9th-10th century. During the tenure of Archbishop Dmitrios Chomatianos (1216-1236), the "pronaos" was replaced with a new church into which the relics of St. Clement were placed. In the Ottoman period, the Church and Monastery of St. Clement were disassembled to build a mosque. At the very beginning of the 10th century, the triconchal church in the Monastery of St. Clement served as a model for the church in the Monastery of St. Naum, in the southern part of the Ohrid lake area. The groundwork(s) of a further church in a triconchal shape, whose construction can be traced back to the time of St. Clement, has also been discovered at Gorica, near Ohrid. Ruins of yet another triconchal church which also belongs to the period under review can be found near the village of Zlesti, in the Dolna Debarca region, not far from Ohrid. In the vicinity of the village of Izdeglavje, in the Gorna Debarca region, there is also a church whose establishment is related to the activity of St. Clement of Ohrid as well. 


\section{Keywords}

Ohrid, St. Clement of Ohrid, Plaošnik, archaeological excavations, triconch church, Monastery of St. Clement, St. Naum of Ohrid, Gorica, Zlesti, Izdeglavje

\section{References}

Angeličin-Žura G., Christian Churches and Sacred Places in the Ohrid Region, Ohrid, 2007.

Bitrakova Grozdanova V., Starohristijanski spomenici vo Ohridsko, Ohrid, 1975.

Bitrakova Grozdanova V., "Lihnid vo ranohristijanskiot period i negovoto urbano jadro," in: Jubileen zbornik 25 godini mitropolit Timotej, Ohrid, 2006, 257-268.

Bošković Đ., Osnovi srednjevekovne arhitekture, Beograd, 1947. 1976.

Bošković Đ., Arhitektura srednjeg veka, Beograd,

Bošković Đ., Tomovski K., "L'architecture medievale d'Ohrid," dans: Recueil de travaux, édition spéciale, Ohrid, 1961, 71-100.

Chaneva-Dechevska N., "Trikonkhalnite tsŭrkvi ot IX-XIV v. po bŭlgarskite zemi," Arkheologiia, 4, 1970, 8-21.

Ćurčić S., Architecture in the Balkansfrom Diocletian to Süleyman the Magnificent, New Haven, 2010.

Grozdanov C., Sveti Naum Ohridski, Skopje, 1995.

Grozdanov C., Kuzman P., Paskali Buntašeska T., Plaošnik: Vozobnovenata crkva na Sv. Kliment i Pantelejmon, Ohrid, 2003. 1931.

Ivanov Y., Bŭlgarski starini iz Makedoniia, Sofia,

Koco D., "Klimentoviot manastir 'Sv. Pantelejmon' i raskopkata pri ‘Imaret’ vo Ohrid," Godišen zbornik na Filosofskifakultet vo Skopje, 1, 1948, 129-182.

Koco D., "Proučavanja i arheološki ispituvanja na crkvata na manastirot Sv. Naum," in: Zbornik na Arheoloskiot muzej: 1957-1958, Skopje, 1958, 56-80.

Koco D., "Trikonhalnite crkvi vo Klimentovoto vreme," in: Slovenska pismenost. 1050-godišnina na Kliment Ohridski, Ohrid, 1966, 91-100.

Koco D., "Novi podatoci za istorijata na Klimentoviot manastir Sv. Pantelejmon vo Ohrid," Godišen zbornik na Filosofski fakultet vo Skopje, 19, 1967, 245-255.

Koco D., "Arheološki proučuvanja vo Ohrid od 1959 do 1965 god," Godišen zbornik na Filosofski fakultet vo Skopje, 19, 1967, 257-266.

Kuzman P., "Praistoriski palafitni naselbi vo Makedonija," in: Makedonija: mileniumski kulturno-istoriski fakti, Skopje, 2013, 297-430.

Kuzman P., Malenko V., "Pregled na srednovekovnite slovenski crkovni gradbi registrirani kako arheološki lokaliteti vo Ohridskata regija," in: Svetiklimentovo slovo, Ohrid, 1992, 78-95.
Lahtov V., "Les bijoux des habitats archeologiques datant du haut moyen age dans la region d'Ohrid," dans: Recueil de travaux, édition spéciale, Ohrid, 1961, 35-70.

Malenko V., "Novi antički naodi vo Ohrid i Ohridsko," in: Živa antika, 28/1-2, Skopje, 1978, 339349 (1-11).

Malenko V., "Lihnidsko-ohridskiot duhoven i kulturen vrutok na Plaošnik," in: Makedonsko-ukrainski kulturni vrski (X-XX vek), 2, Skopje, 2004, 279-297.

Malenko V., Kuzman P., "Hermeleja," in: Lihnid. Zbornik na trudovi, 6, Ohrid, 1988, 89-116.

Malenko V., Kuzman P., "XX. Ohrid," in: Arheološka karta na Republika Makedonija, 2, Skopje, 1996, 238-279.

Miljkoviḱ-Pepek P., "Hristijanskata arhitektura kaj Makedonskite Sloveni od pred sredinata na IX vek do 1018 godina," in: Kliment Ohridski. Studii, Skopje, 1986, 225-237.

Muçaj S., Xhyheri S., Ristani I., Pentkovskiy A. M., "Medieval Churches in Shushica Valley (South Albania) and the Slavonic Bishopric of St. Clement of Ohrid," Slověne, 3/1, 2014, 5-42.

Panov B., "Ohrid i Ohridsko vo ranofeudalniot period," in: Ohrid i Ohridsko niz istorijata, 1, Ohrid, Skopje, 1985, 173-197.

Pentkovskiy A. M., "The Cult of St Clement of Ohrid Between the Tenth and the Fourteenth Century," Starobŭlgarska literatura, 48, 2013, 79-113.

Počuča Kuzman N., Krstovi-relikvijari - kataloška obrabotka. Istražuvanja 1999-2000. Dvižen arheološki materijal. Plaošnik, 2000. Proektna programa (elaborat), Zavod za zaštita na spomenicite na kulturata i Muzej-Ohrid, Ohrid, 2000.

Počuča Kuzman N., Aceski S., "Krstilnica na Plaošnik, Ohrid," Makedonski arheološki pregled, 1, 2008, 228-232.

Počuča Kuzman N., Bocevska V., Aceski S., Angeličin-Žura G., "Ranohristijanska bazilika (narteks) na Plaošnik, Ohrid," Makedonski arheološki pregled, 1, 2008, 233-243.

Počuča Kuzman N., Karpuzova S., Miševa O., "Plaošnik, Ohrid," Makedonski arheološki pregled, 1, 2008, 244-250.

Radojčić S., "Crkva u Konjuhu," Zbornik radova Vizantoloskog instituta, 1, 1952, 148-67.

Stričević Đ., "Èglises triconques médiévales en Serbie et en Macédoine et la tradition de l'archi- 
178 The Archaeological Evidences of St. Clement of Ohrid's Activities in Ohrid Region

tecture paléobyzantine," dans: Actes du XII congrès international d'etudies Byzantines, Ochride 1016 septembre 1961, 1, Beograd, 1963, 224-240.

Tunitskiy N. L., Materialy dlia istorii zhizni i deiatel'nosti uchenikovsvv. Kirilla i Mefodiia, 1, Sergiyev Posad, 1918.

Tutkovski M., Ranohristijanskite mozaici od Ohrid, Skopje, 2014.

Vasiljević D., "Trikonhos u selu Zlesti. Prilog Milana Kašanina istoriji srednjovekovne arhitekture," u: Zbornik Narodnog muzeja, 12/1: Arheologija, Beograd, 1986, 243-253.

Vulić N., "Antički spomenici naše zemlje," Spomenik Crpske kraljevske Akademije, 77, 1934, 31-84.

Xhyheri S., Muçaj S., Pentkovskiy A., Ristani I., "Kërkime arkeologjike në krahinën e Vlorës, Mallakstrës, Myzeqesë dhe Korçës (Korridori VlorëPrespë, raport 2013-2015)," Candavia, 6, 2016, 279-314.

\section{Паско Кузман}

археолог, кустос

Заводот за заштита на спомениците на културата и Народен музеј во Охрид, Ул. Боро Шаин 10, Охрид

Македонија / Republic of Macedonia

paskokuzman@gmail.com

Received September 15, 2016 